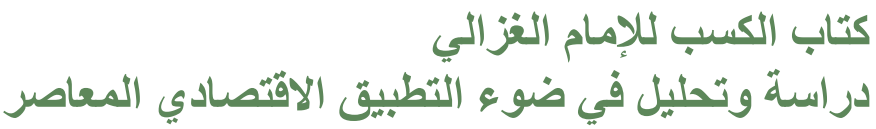

\title{
Kitab al-Kasb by Imam Al Ghazali Study and Analysis in Light of Contemporary Economic Application
}

\author{
Heba Mohammad Alshorman $^{1}\left(\mathbb{0}\right.$, Abdalnaser Abu Albasal $^{2}$
}

Sorumlu yazar/Corresponding author:

Heba Alshorman, Yarmouk University, Irbid, Jordan

E-posta: hebamshorman96@gmail.com ORCID: 0000-0002-5599-9347

${ }^{2}$ Abdalnaser Abu Albasal, Yarmouk University, Irbid, Jordan

ORCID: 0000-0002-0455-9907

Başvuru/Submitted: 11.02.2021 • Revizyon Talebi/Revision Requested: 10.08.2021 • Son Revizyon/Last Revision Received: 16.08 .2021 •

Kabul/Accepted: 16.08 .2021

Atıf/Citation: Alshorman, Heba Mohammad \& Abu Albasal, Abdalnaser. Kitab al-Kasb by Imam Al Ghazali Study and Analysis in Light of Contemporary Economic Application. Islam Tetkikleri Dergisi-Journal of Islamic Review 11/2 (Eylül 2021): 987-1011.

https://doi.org/10.26650/iuitd.2021.878420

\section{ABSTRACT}

This research deals with the study and analysis of "Kitab Alkasb" from the book "Ihya Ulum al-Deen" of Al-Ghazali, and aims objectively to identify the controls contained in the book, extrapolating and analyzing in the light of the contemporary Islamic economic application in light of what the economy has reached today.

This research referred to al-Ghazali's most important statements concerning earnings, its controls and methods, and presented it to the economic realities that we live today, by presenting contemporary economic applications related to the controls and provisions he referred.

This research concluded to a set of results, and its total, that the book of Alkasb of Al-Ghazali formes a rich and important base that will control the behavior of the customers in the market and provide them with what they care about in daily transactions, as well as establish a strong structure that regulates and controls market practices, in addition to the fact that the economic relations of individuals in the market depend on the existence of cooperative motives based on the base of The deen (religion) is naseehah (advice, sincerity), and the application of this rule and the following market controls, which would achieve fair competition among the customers, It brings the market to a better position than full competition.

Keywords: Al-Ghazali, Al-kasb, Selling, Riba, advice, sincerity 
الحمد لله رب العالمين، و العاقبة للمتقين، وأشهد أن لا إله إلا الله وحده لا شريك له، و أشهد أن محمداً عبده ورسوله،

صلى الله وسلم عليه و على آله و أصحابه أجمعين. أما بعد: جاءت الثريعة الإسلامية لتحقق الحياة الكريمة للإنسان؛ فوضعت بعان جملة من التشريعات و القو اعد لتبين من خلالها ما فيه مصلحة وما فيه ضرر، و القصد من هذه التشريعات و الاو امر و النو اهي حفظ الضروريات الخمس، و ونها حفظ المال، الذي به قو ام الحياة ولذلك يسعى الإنسان لتحصيله بما يناح لله من وسائل الكسب.

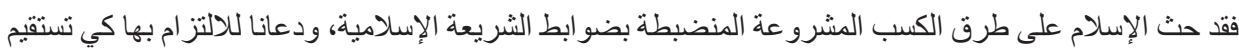
أمورناوتوزن في ميز ان صحيح لا رجحان فيه لكفة دون كفة، و على ذلك نظمت الثريعة الإسلامية طرق الكسب و أولتها

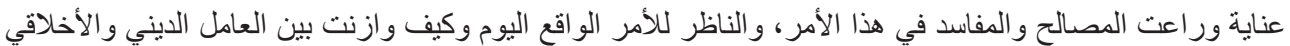

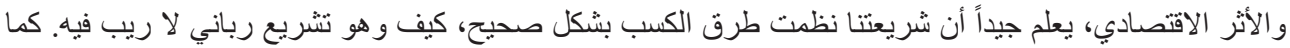
أولى الفقهاء و الأئمة اهتماما بالعمل و الحث عليه و عقدو الذلك كتباو أبو ابا في مصنفاتهم، لما له من أبعاد دينية ودنيوية و آثار

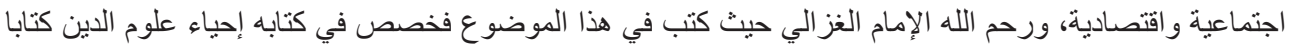

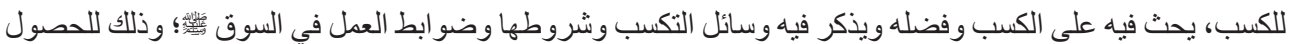

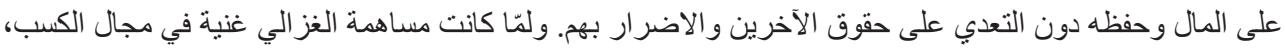

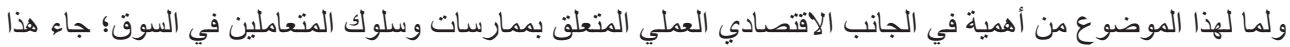
البحث ليسلط الضوء على أهم ماورد عند الامام الغز الي في هذا الجانب. ونتمثل مشكلة الدر اسة في الوقوف الموضو عي في في في

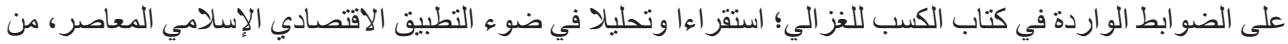
خلال اسقاط ما أورده الغز الي في كتاب الكسب على المعاملات الاقتصادية المستجدة، وذللك بالإجابة على الأسئلة التالية:

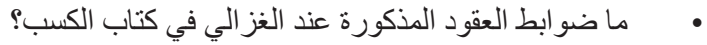

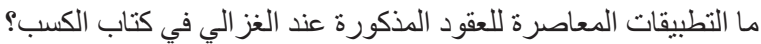

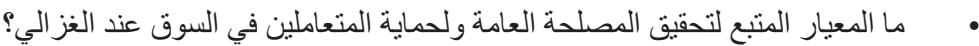
ويكمن هدف الدر اسة في تحقيق الآتي: الوقوف على الضو ابط الواردة في كتاب الكسب للغز الي استقر اءا وتحليلا في

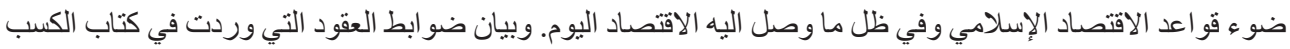
و الوقوف على التطبيقات المستجدة و المعاصرة لهذه العقود. وبيان ضو ابط الكسب المتعلقة بالمصلحة العامة عند الغز الي

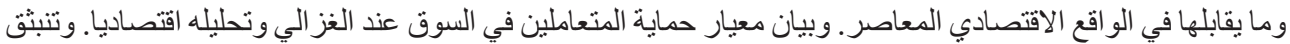

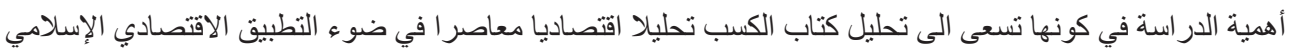

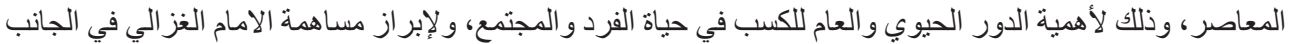

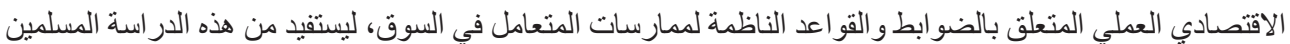

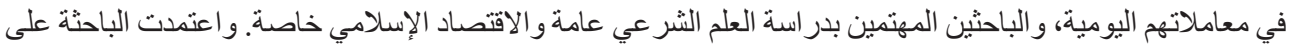

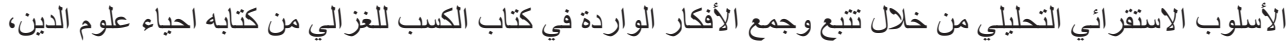

وربطها بالدر اسات الاقتصادية الإسلامية المعاصرة.

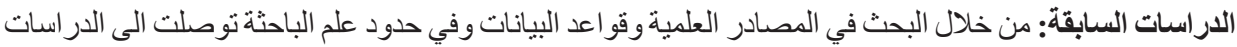
الآتية: أولاً: دراسة السناني "2016": "طرق الكسب عند الامام الغزالي وآثاتثار ها الاقتصادية من خلال كتابه احياء علوم

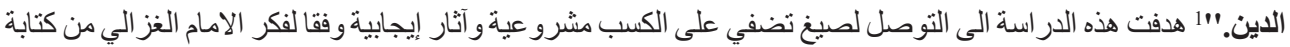

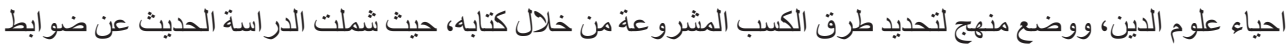

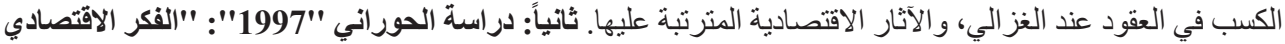

1 1 السناني، محمد، طرق الكسب عند الامام الغزالي وآثارها الاقتصادية من خلال كتابه احياء علوم الدين، رسالة ماجستير، الجامعة الإسلامية،

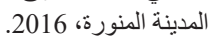




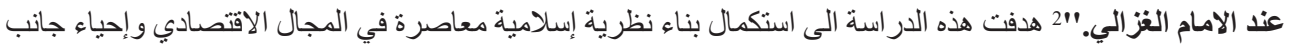

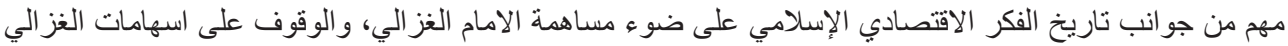

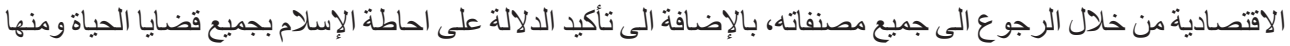

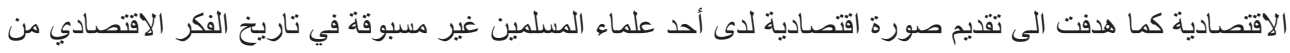

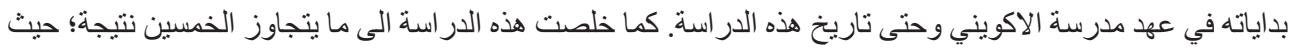

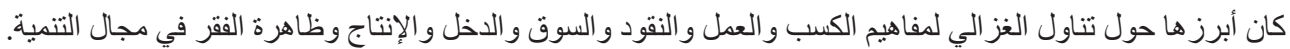

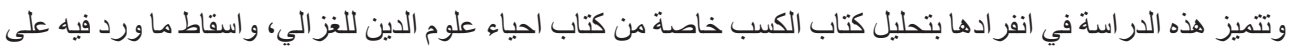

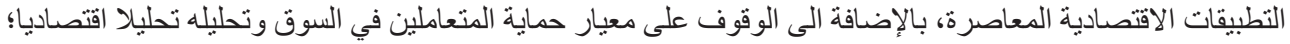

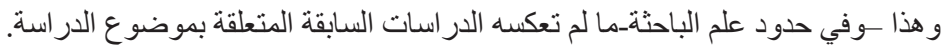

\section{مبحث تمهيدي}

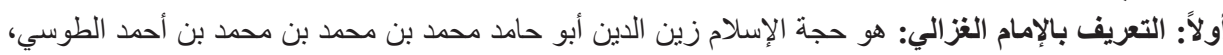

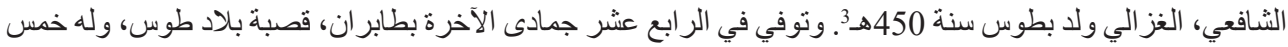

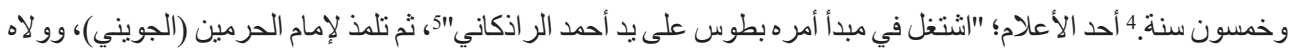

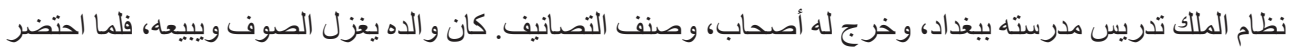

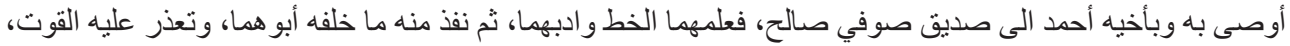

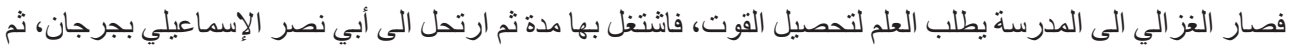

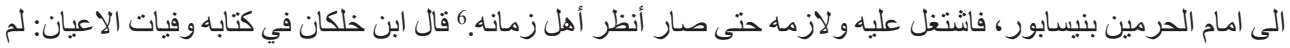

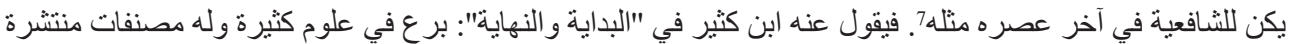

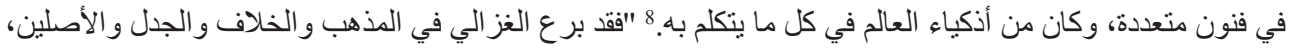

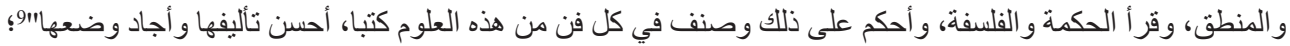

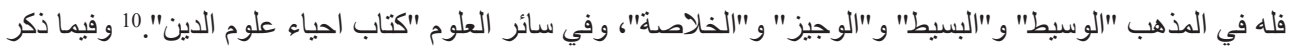

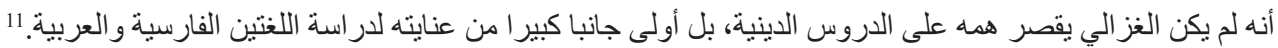

\section{ثانياً: التعريف بكتاب احياء علوم الدين، وكتاب الكسب:}

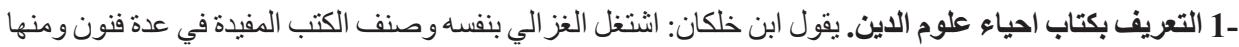

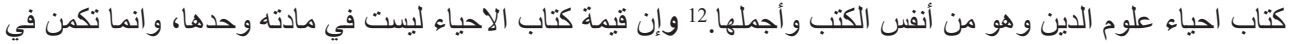

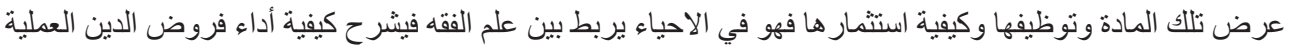

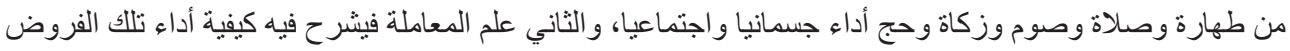

2 2 2

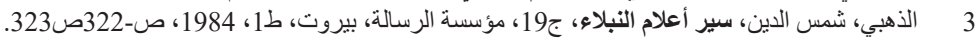

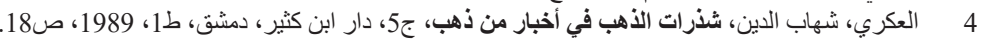

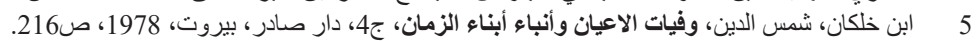
6 7

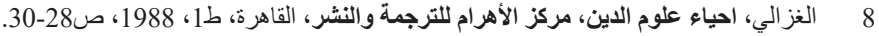
9 10 11

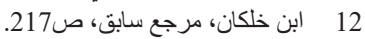


نفسها أداء روحيا بحيث يصبح الفقه فقهين، فقه المعاملة الجسمانية، وفقه المعاملة القلبية الروحية. 13 ويقول الغز الي في مقدمة الاحياء ان ما يميز هذا الكتاب عما صنفه الناس في بعض معانيه خمسة أمور وهي: "حل ما عقدوه وكثف ما أجملوه"،

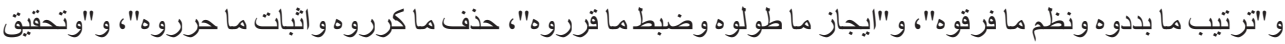

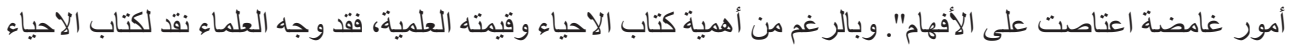

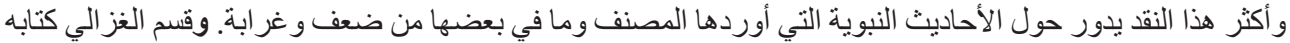

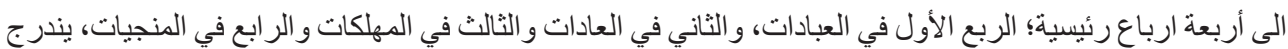

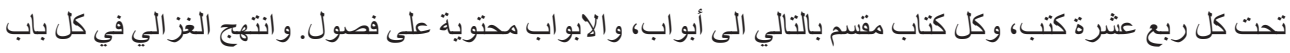
من الأبو اب منهجية متناسقة ترتبط بوحدة الموضوع محل البحث، وتقوم هذه المنهجية على الابتداء بالمقدمة متضمنه الحمد

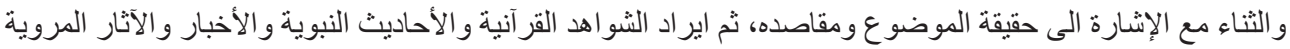

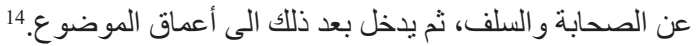

-2 كتاب الكسب. و أما كتاب "آداب الكسب و المعاش" فهو الكتاب الثاني في ربع العادات، من كتاب احياء علوم الدين، وقد قسم الى خمسة أبو اب: منها في "فضل الكسب و الحث عليه"، ويستند الغز الي فيه الى ما ورد في القر آن الكريم و الأخبار و الآثار من نصوص تحث على الكسب و السعي في طلب الرزق، وفيه يقول الغز الي: "وليكن العقد الذي به الاكتساب جامعا

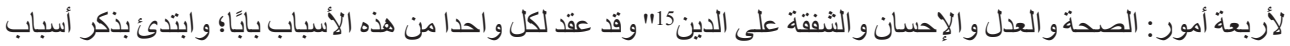

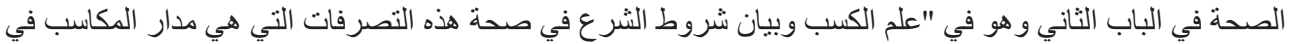

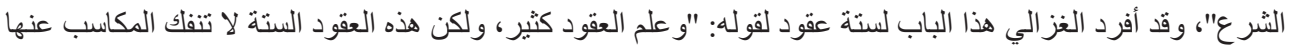

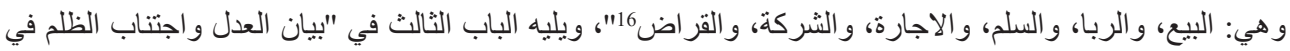

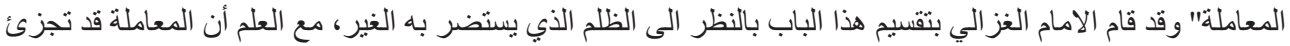

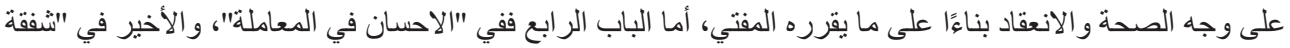
التاجر على دينه فيما يخصه و ويعم آخرتهه". -3 مفهوم الكسب، وأهميته. و الكسب في اللغة: مأخوذ من كسبه يكسبه كسبا، وتكسب و واكتسب: طلب الرزب وزت وكسبه

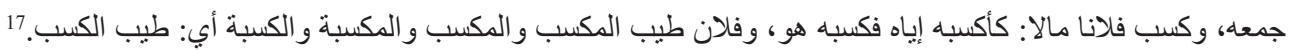

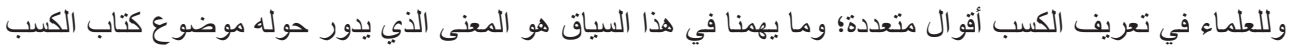

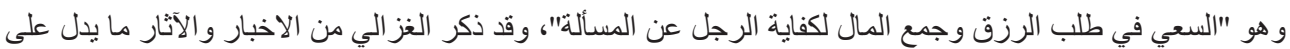

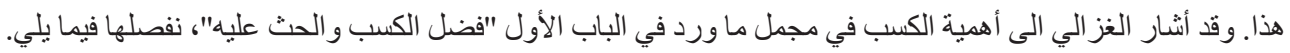

$$
\text { -1 الكسب و السعي في طلب الرزق يحد من البطالة و الجوع. }
$$

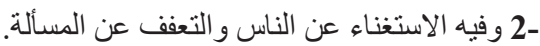

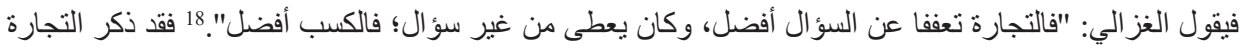

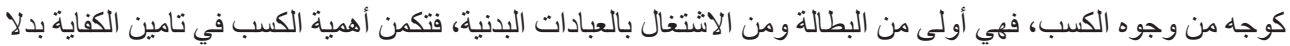

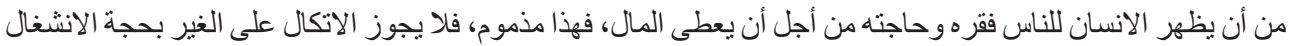

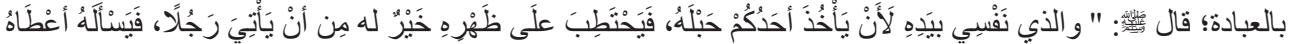

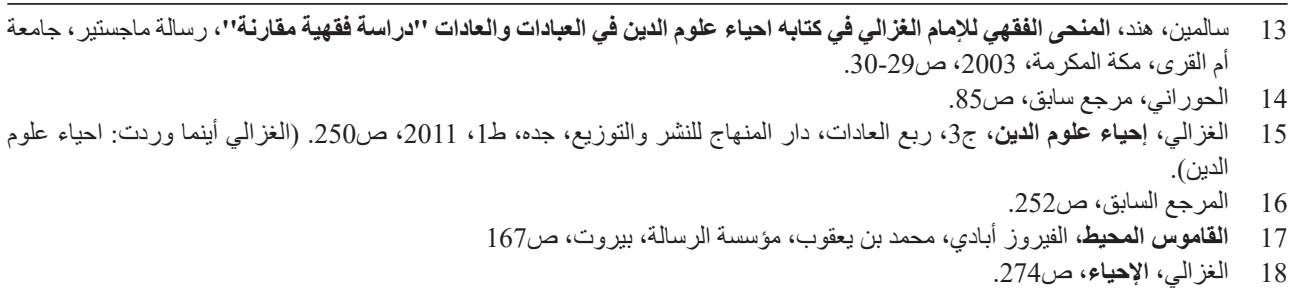


أوْ مَنَعُهُ."19 و العمل في التجارة ـعلى سبيل المثال_من شأنه أن يحد من البطالة، فلا ينحصر العمل فقط في مؤسسات الدولة الحكومية و غير ها من المنشآت الخاصة. توفير حد الكفاية: وقد أثار الغز الي الى أنه للإنسان أن يطلب الكفاية، أو ما يزيد عن كفايته وكفاية من هو مسؤول

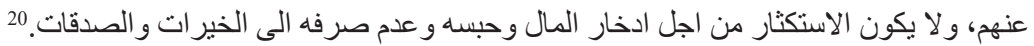

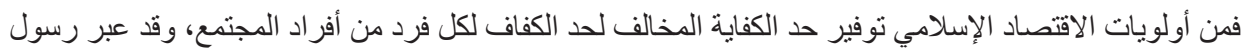

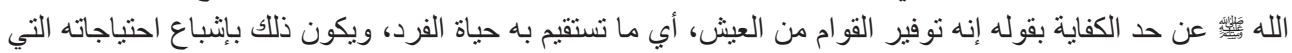

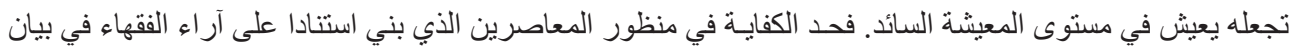

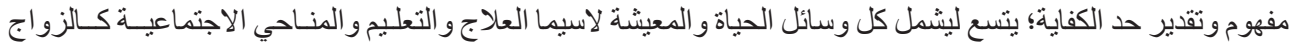
و غيـره بمـا يجعـل الإنسـان غير محتــاج و لا عـائز لأحد.

\section{المبحث الأول: ضوابط العقود فيما ذكر عند الغزالي، وتطبيقاتها المعاصرة:}

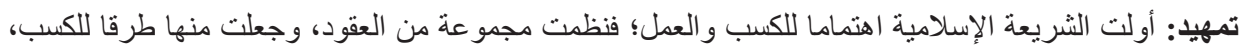

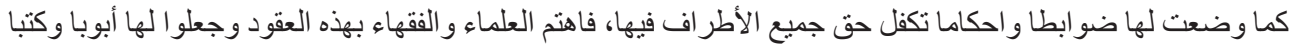

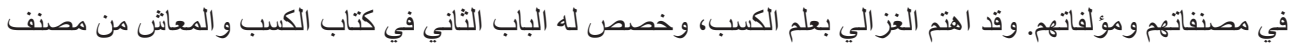

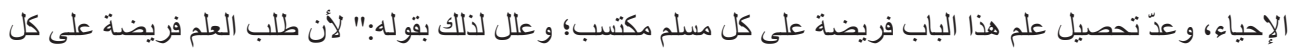

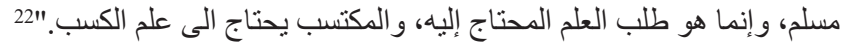

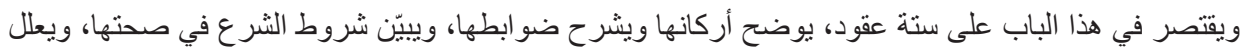

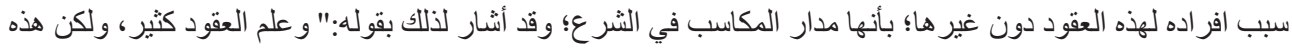

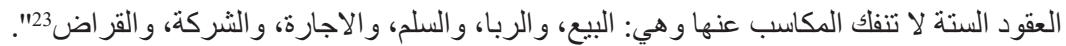

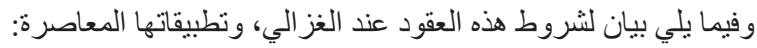

المطلب الأول: ضوابط البيع وأحكام الربا من خلال كتاب الكسب: يعد البيع من أهم مجالات التعامل التجاري في

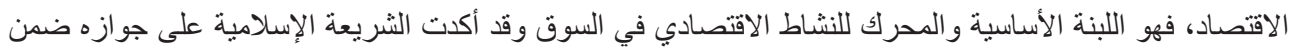

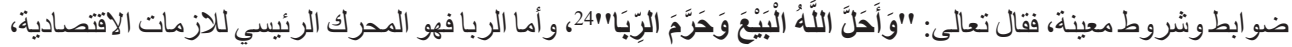

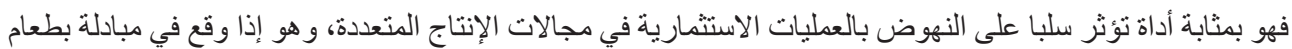

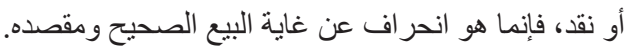

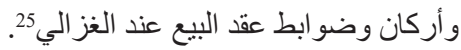

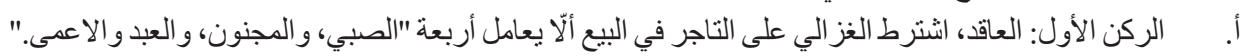
ب. ب. الركن الثاني: في المعقود عليه، وقد عرفه بقوله:" وهو المال المقصود نقله من أحد العاقدين الى الآخر ثمنا

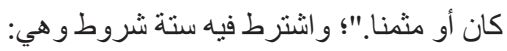

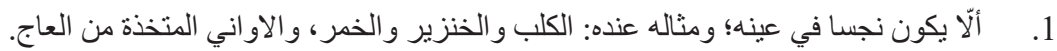

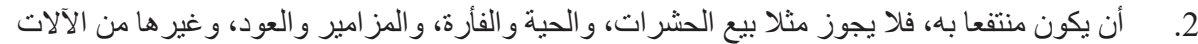

الموسيقية.

19 19

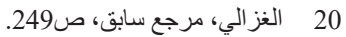

21 انظر : قنديل، محمد، حد الكفاية وأثره في تحقيق المصالح، مجلة كلية الثريعة و القانون، طنطا، ج35، ع2، ص50، 2020، 2020، بتصرف

22

23 25 المرجع السابق، ص252.

24

25 2 24 
3. أن يكون مملوكا للعاقد، فلا يجوز أن يشتري من غير المالك؛ إلا أن يأذن الماللك لغيره بالتصرف بالمعقود عليه.

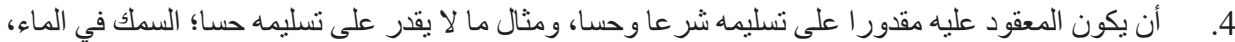

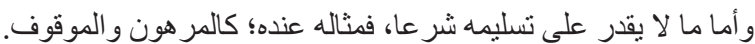

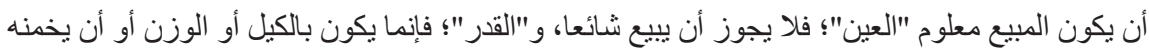

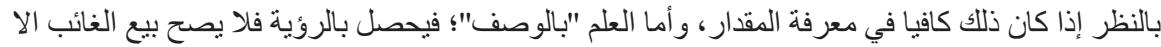

إذا سبقت رؤيته منذ مدة لا يغلب التغير فيها.

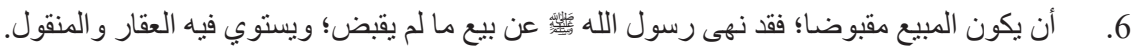

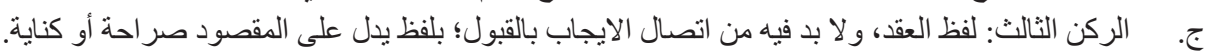
الربا في نظر الغزالي: يشير الغز الي في الوسيط الى أن الربا في النقدين عند الثافعية، معلل بكونهما (الذهب والفي والفضئة

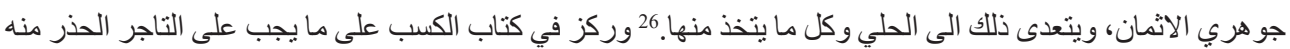

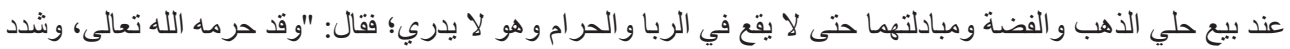

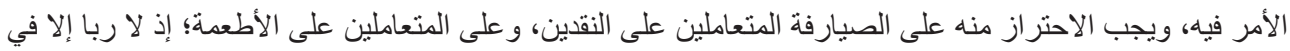

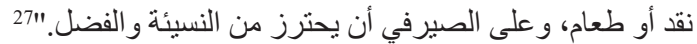

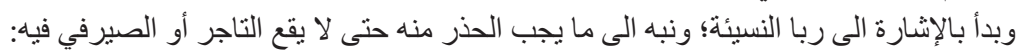

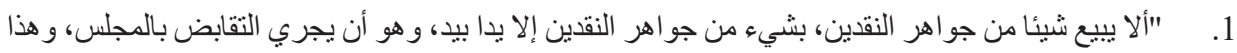

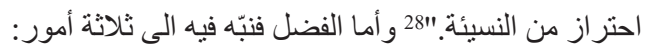

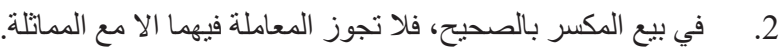

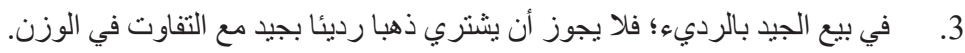

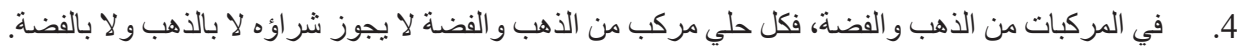

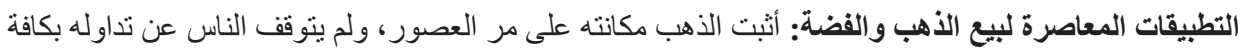

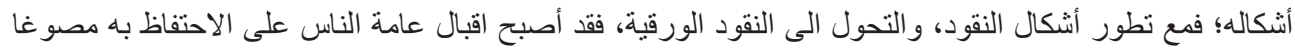

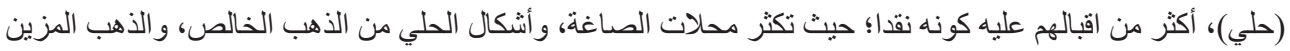

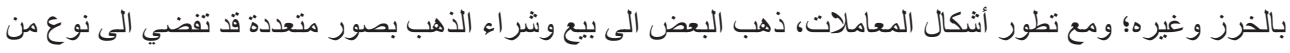

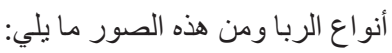
أ. الصورة الأولى: بيع حلي الذهب والـئ الفضة مؤجلا؛ فقد يشتري أحدهم ذهبا بالنقو د مع بقاء شيء من ثمنه في ذمته ومثاله:

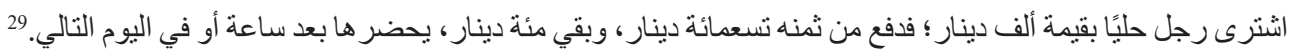

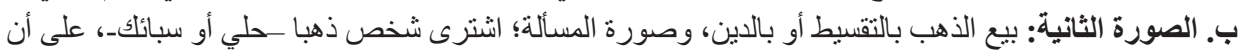

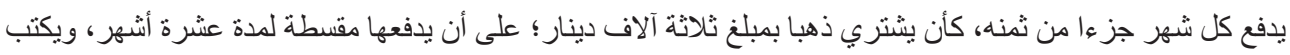

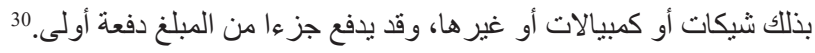

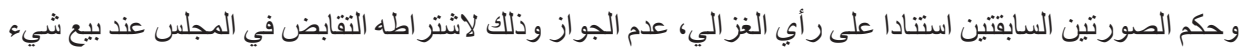

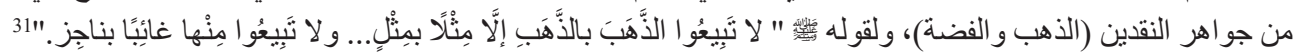

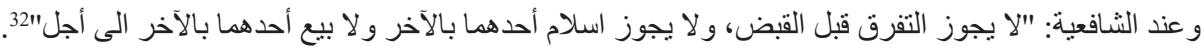

$$
\begin{aligned}
& 26 \text { 2 الغز الي، الوسيط في المذهب، ج3، دار السلام للطباعة والنشر، الأزهر، ط1، 1997م، ص46. } \\
& 27 \text { الغز الي، الإحياء، ص266. } 26 \\
& 28
\end{aligned}
$$

29 حسين، صدام عبد القادر، بيع الذهب والفضة وتطبيقاته المعاصرة في الفقه الإسلامي، رسالة ماجستير، الجامعة الأردنية، عمان، 2003م، 


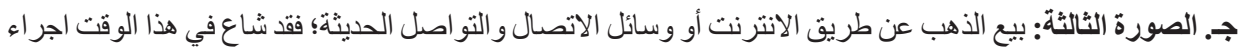
المعاملات التجارية عن طريق مواقع التو اصل الاجتماعي، سواء كان ذلك عن طريق المكالمات الصوتية أو المحادثات

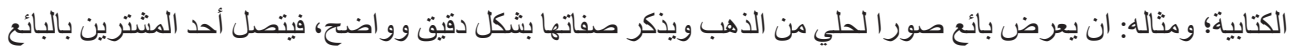

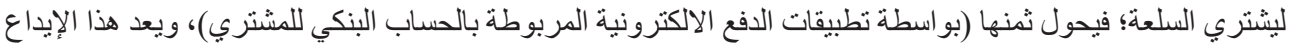

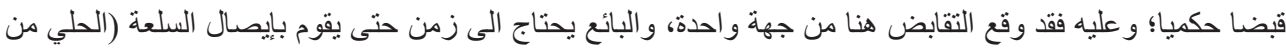

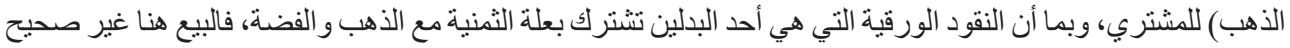

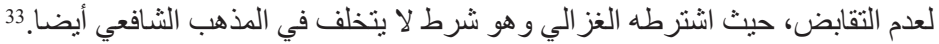

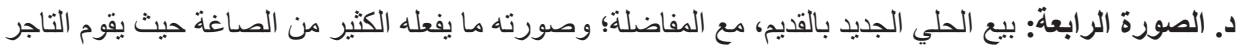

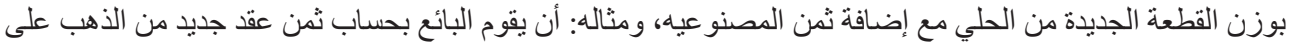

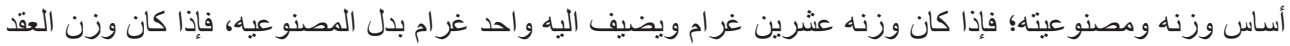

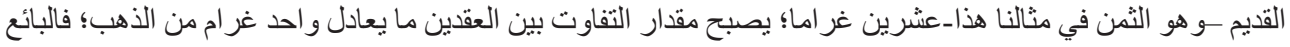

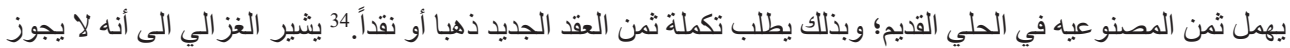

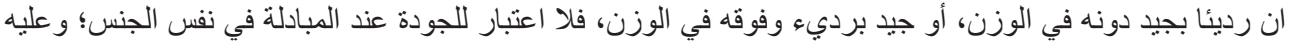

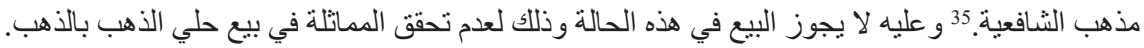

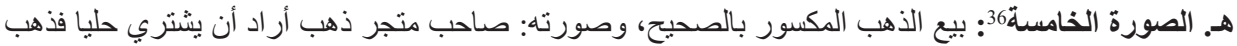

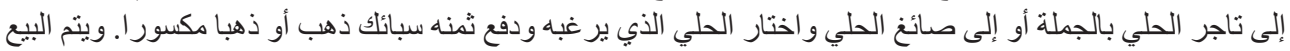

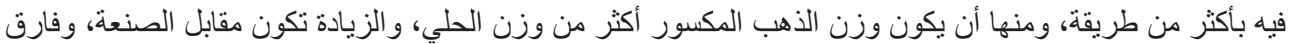

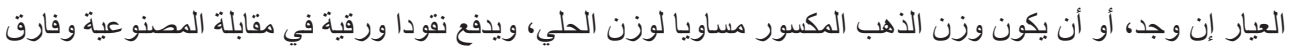

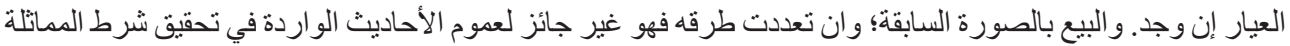

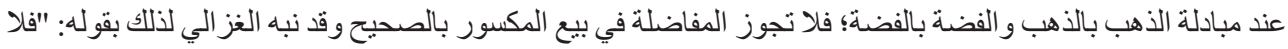

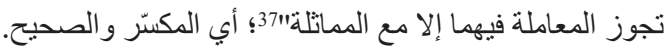

\section{المطلب الثاني: التطبيقات المعاصرة لعقدي "السلم والاجارة" والضوابط المتعلقة بهما:}

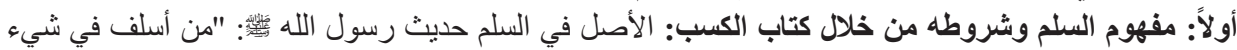

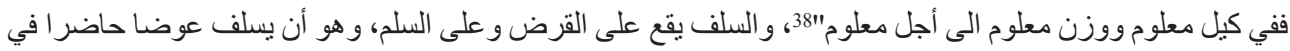

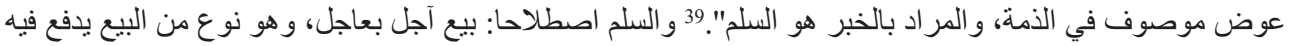

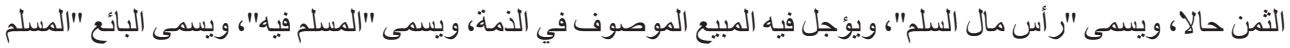

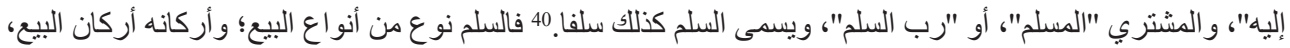

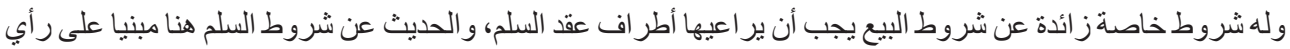

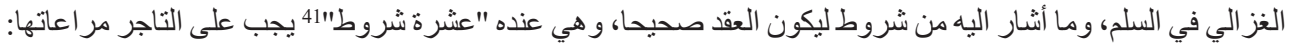

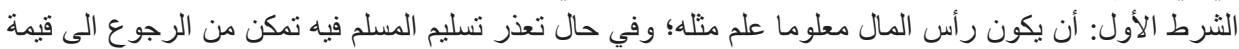

رأس المال.

33 انظر : بن باز، هند عبد العزيز، بيع الذهب بالآجل وصوره المعاصرة، مركز التمبز البحثي، جامعة الامام محد بن سعود الإسلامية، الرياض،

ص24.

34 3 انظر : حسين، مرجع سابق، ص130

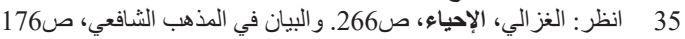

36 3 35 37 3 38

38 38 39 38 38

40 أبو العز، علي، عقود التمويل الإسلامي تتبيهات وملاحظات شرعية، دار الإني، النفائس، عمان، ط1، 2019م، ص234.

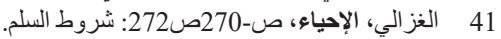


الثرط الثاني: أن يسلم رأس المال في مجلس العقد قبل التفرق، فإن تفرقا قبل القبض انفسخ السلم.

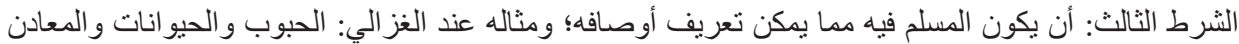

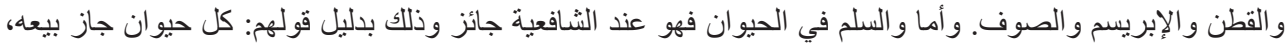

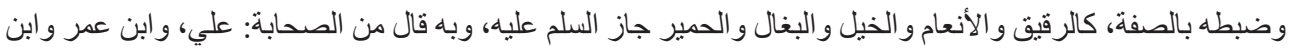
عباس، ومن التابعين: سعيد بن المسيب، و الحسن البصري، و النخعي، ومن الفقهاء مالك واحمد"

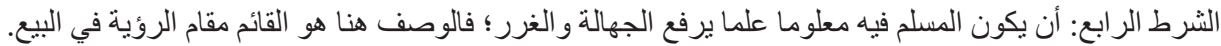
الشرط الخامس: أن يجعل الأجل معلوما ان كان مؤجلا؛ فلا يجب أن يقول الى الحصاد أو الى وقت إدر الك الثمار ؛ بل

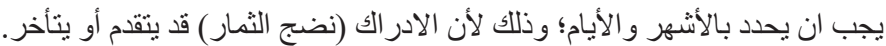

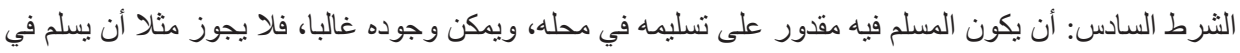

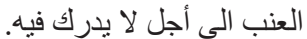

الشرط السابع: أن يتم تعيين مكان التسليم وتحديده، حنى لا يقع النز اع و الخلاف بين أطر اف العقد.

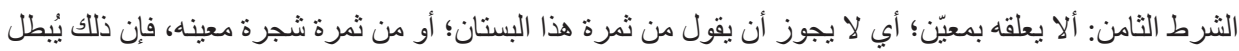

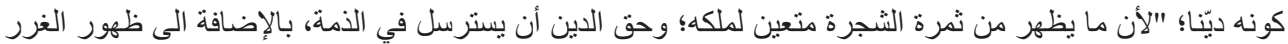

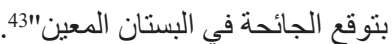
الثرط التاسع: ألّا يسلم في شيء نفيس عزيز التئ الوجود؛ ومثاله: اللآلى و الجواهر والياقوت، أو غير ذللك مما لا يقدر

عليه غالبا. الثرط العاشر : ألّا يسلم في طعام إذا كان ر أس المال طعاما، سواء كان من جنسه أو لم يكن، و لا يسلم في نقد إذا كان رأس المال نقدا؛ حتى لا يقع في الربا. التطبيقات المعاصرة لعقد السلم: تطبيق عقد السلم في المجال الزر اعي: يعتبر نطاق التعامل المشروع لعقد السلم في

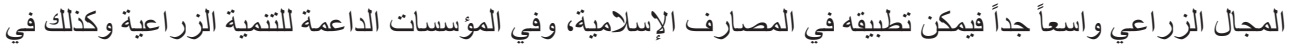

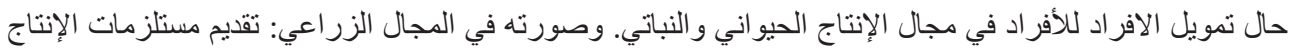

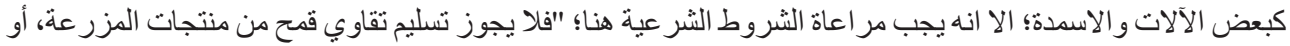

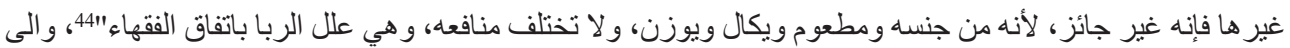

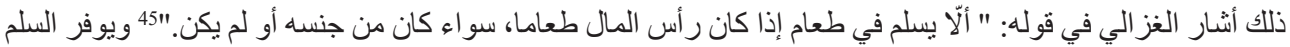

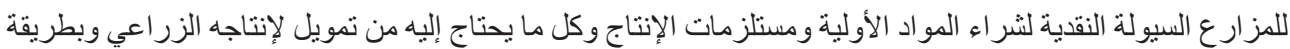

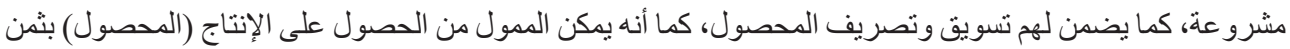

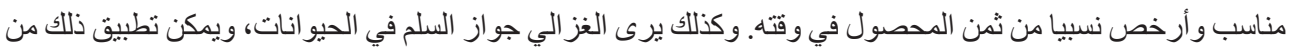

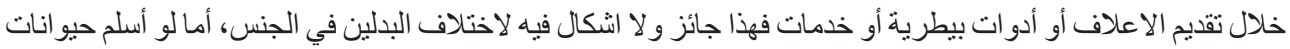

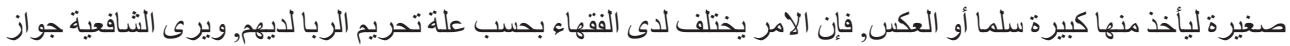

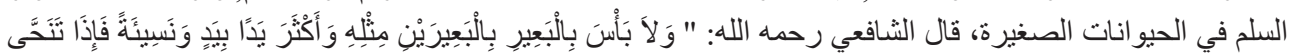

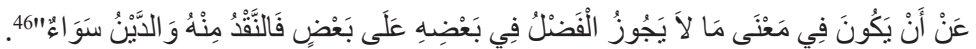

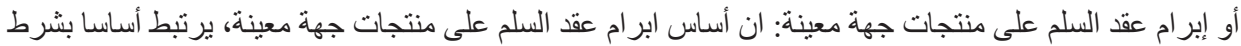

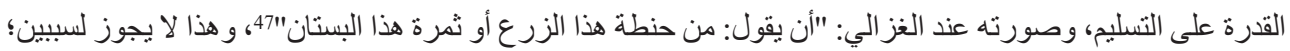


ففي حال تم تحديد المنتجات المسلم فيها بإنتاج مزرعة معينة فقد تصييها آفة ويتعذر التسليم، و هذا غرر لا حاجة اليه

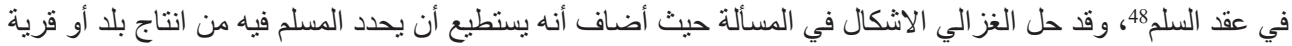

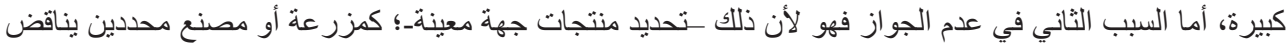
شرط ثبوت المسلم فيه دينا في الذمة؛ لان السلم يكون في دين موصوف في الذمة لا في شيء بعينه، و هذا ما أثرنا اليه في شروط الغز الي لعقد السلم. أو تطبيق عقد السلم في المجال الصناعي: كما هو الحال في المجال الزر اعي؛ يعد مجال التعامل بعقد السلم في المجال

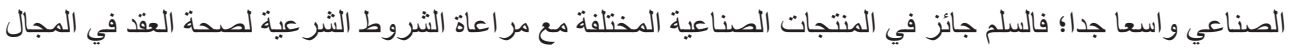

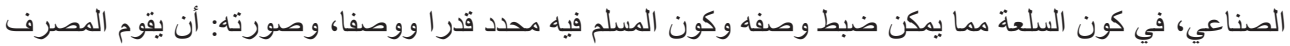

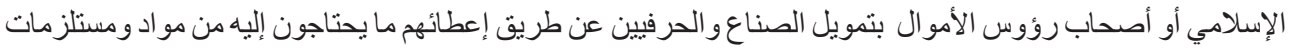

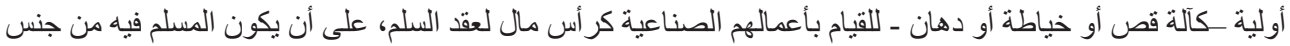

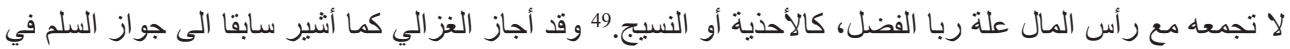
الصوف و القطن و الحرير (النسيج)، إلا أنه و على شرط الغز الي لا يجوز السلم في الخفاف و النعال (الأحذية)؛ وذللك لكونه

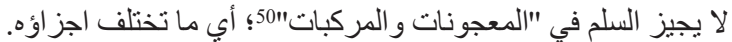

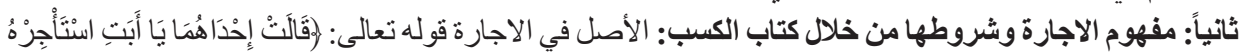

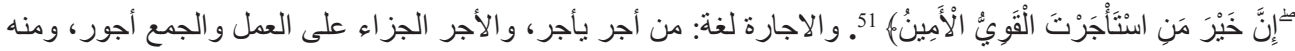

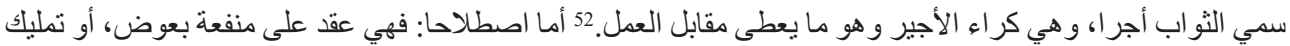

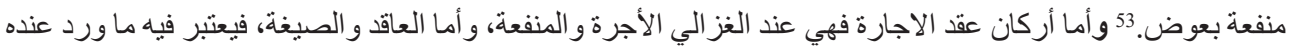

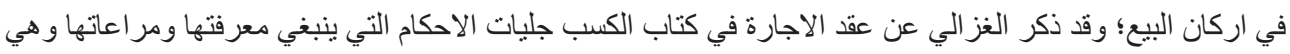
شروط مسائل يجب مر اعاتها في الأجرة و المنفعة حتى يكون العقد صحيحا، وفيما يلي التفصيل:

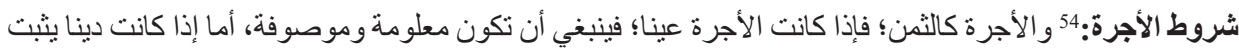

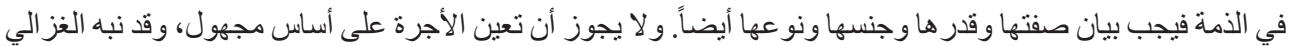

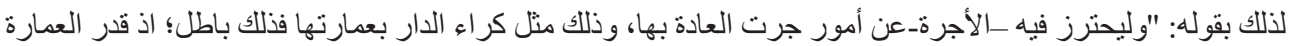

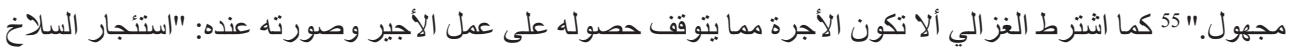

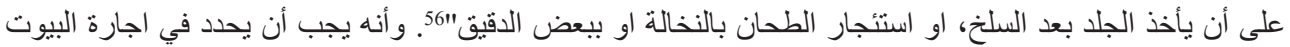
و المحال و غبر ها المدة مع الأجرة فلا يكفي أن يقول، لكل شهر كذا، دون أن يحدد عدد الأشهر فبذلك تكون المدة مجهولة ولا تنعقد الاجارة في هذه الحالة عنده.

\section{شروط المنفعة المقصودة بالإجارة:57}

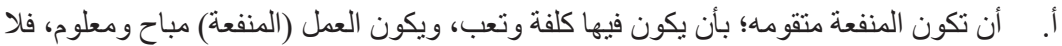

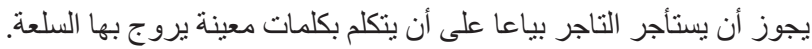

48 انظر : الثديفات، زيد قاسم، عقد السلم كأداة لتمويل المشروعات الصغيرة والمتوسطة وتطبيقاته المعاصرة، رسالة ماجستير ، جامعة آل البيت،

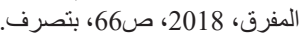

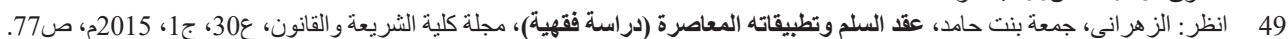
50

51 51

52 53

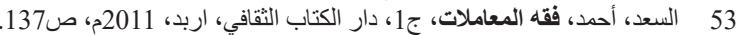

54 انظر: الغزالي، الإحياء، ص273 53

55 5 الغز الي، الإحياء، صنزي، الاحياء، 54

56

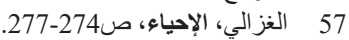


ب. ألا تتضمن الاجارة استيفاء عين مقصودة؛ أي أن يستأجر البستان لثماره، أو المو اشتي للبنها،

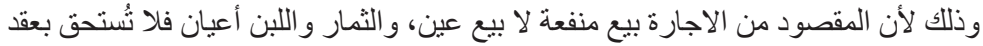
الاجارة.

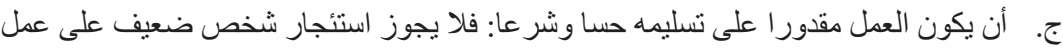

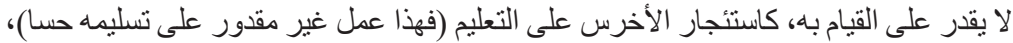

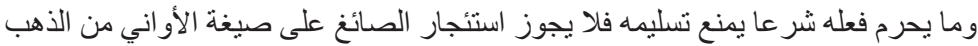
و الفضة.

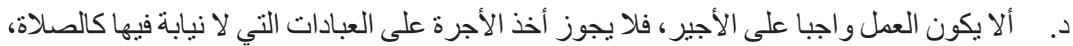

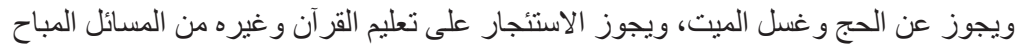

ه. أن يكون العمل و المنفعة معلوما، فلا يجوز اهمال التفاصيل المتعلقة بالعمل والتي من شأنها أن

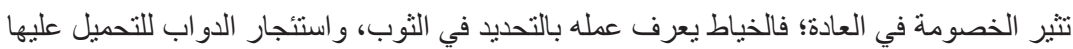
يُعرف بمقدار المحمول عليها وبمقدار المسافة. و اكتفى الغز الي بذكر هذه الثروط في كتاب الكسب من كتاب احياء علوم الدين.

\section{التطبيقات المعاصرة لعقد الاجارة:}

الاجارة المنتهية بالتمليك: يعتبر عقد الاجارة المنتهية بالتمليك من العقود المعاصرة ومن النوازئ المال الفقهية التي انتشرت

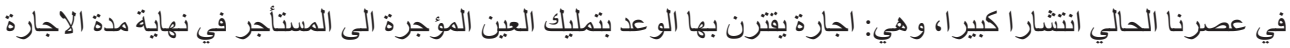
أو في أثنائها. 58 ويلاحظ على تطبيق هذا العقد في المصارف و المؤسسات المالية الاسلامية جملة من الملاحظات الثر عية،

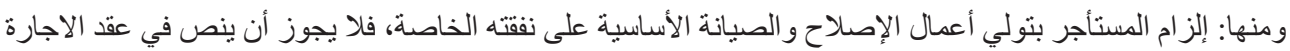

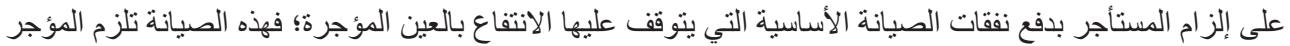

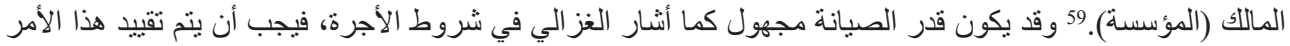

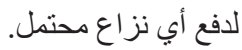

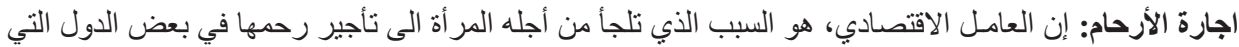

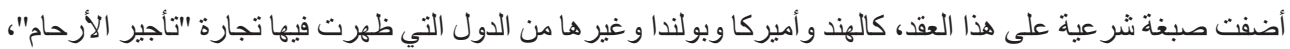

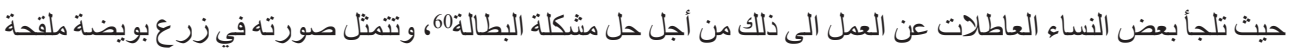

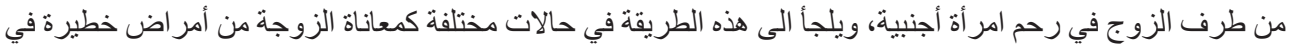

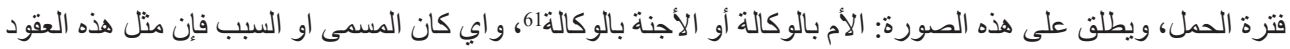

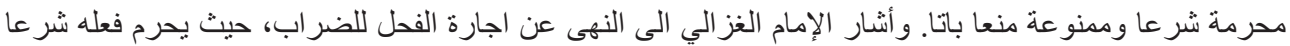

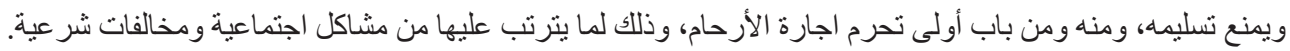

\section{المطلب الثالث: التطبيقات المعاصرة لعقدي "القر اض والثركة" و الضوابط المتعلقة بهما}

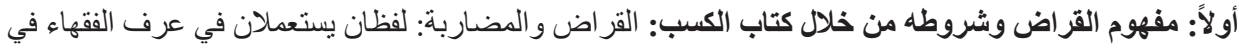

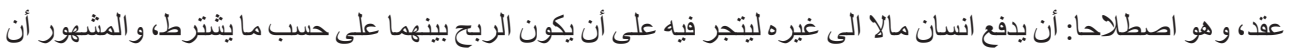


القر اض لغة أهل الحجاز. 62 وتعرف المضاربة أيضاً: بأنها اتفاق بين طرفين يبذل أحدهما فيه ماله ويبذل الآخر جهده ونشاطه

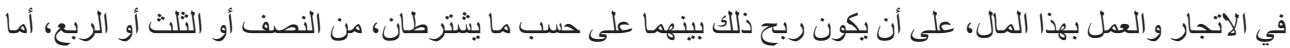

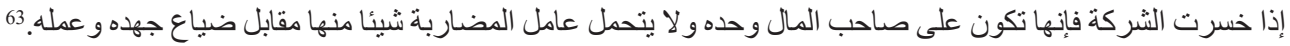

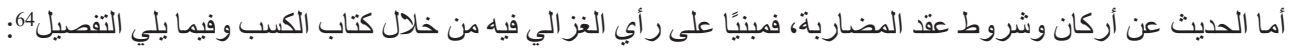

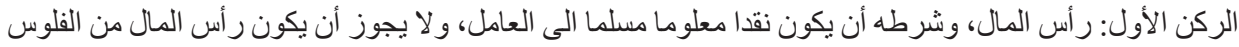

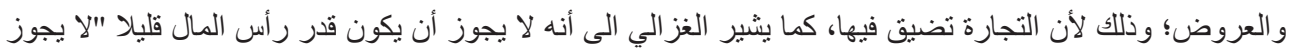

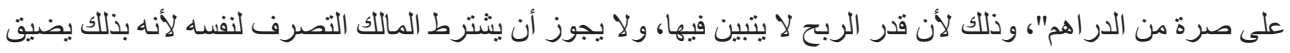

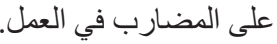

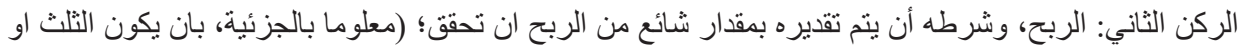

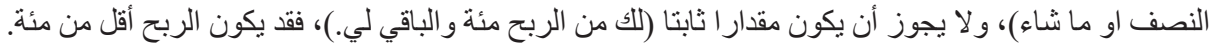

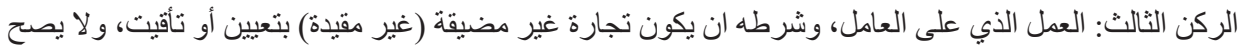

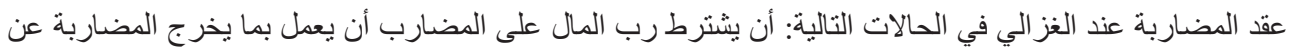

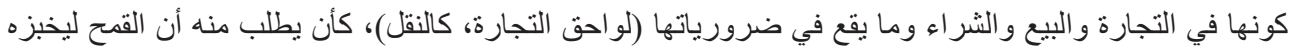

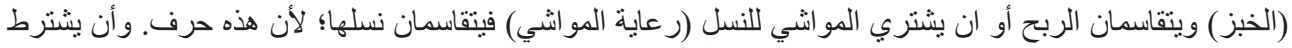

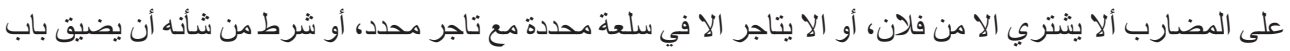

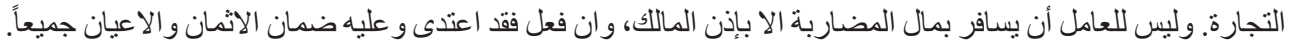

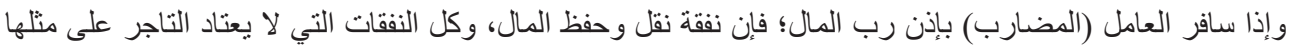

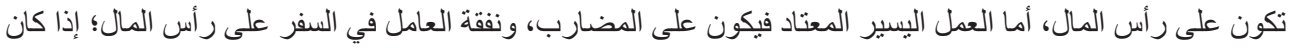

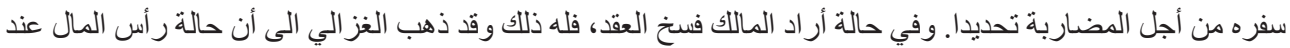

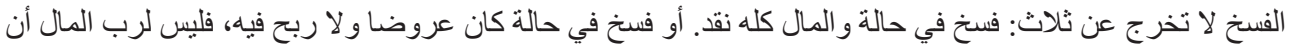

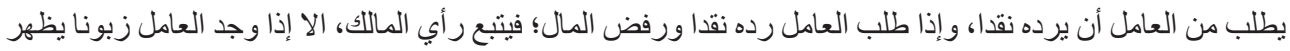

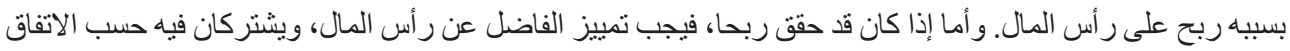

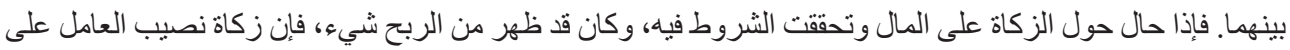

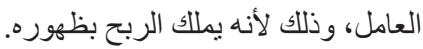
التطبيقات المعاصرة لعقد القراض (المضاربة) إن الفقه الإسلامي قادر على استيعاب كل صور المعاملات الجديدة

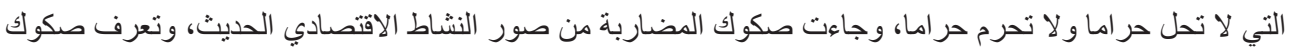

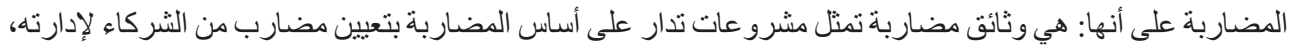

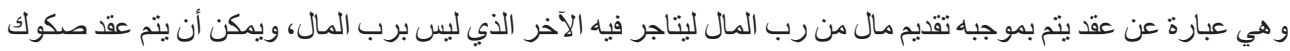

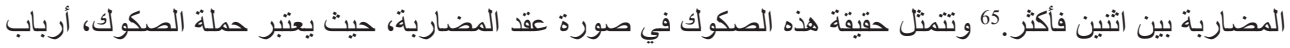

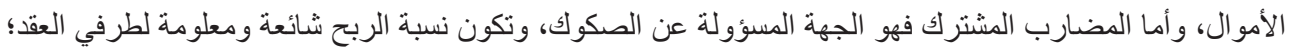

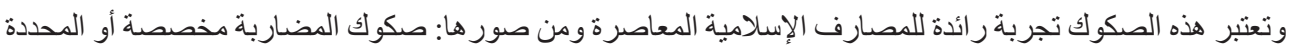

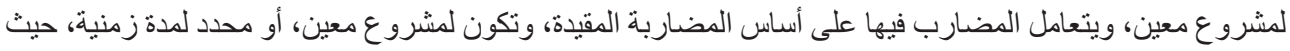

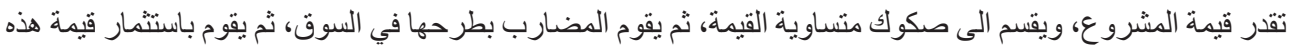

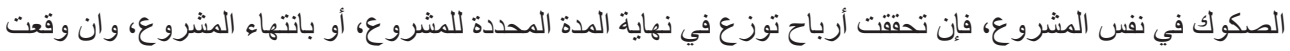




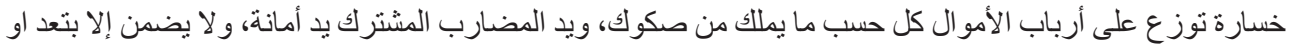

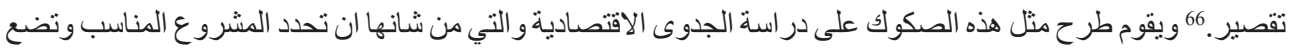

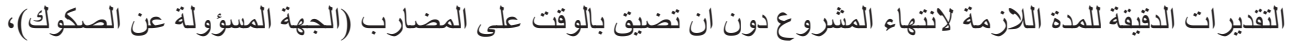

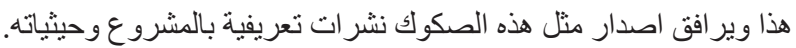

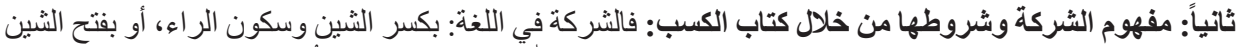

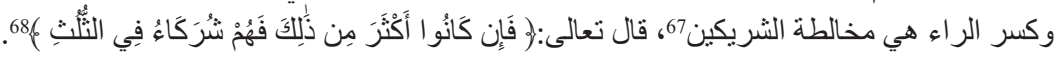

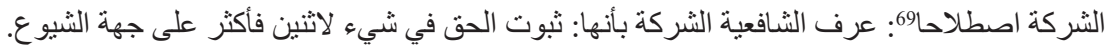

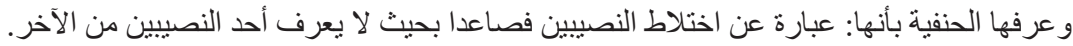

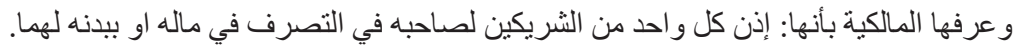

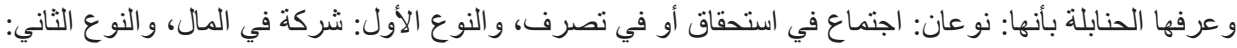

أنواع الثركات عند الغزالي، وصحتها: وقد أشار الغز الي في كتاب الكسب الى أربعة أنواع من الثركات؛ ثناثة منها عنده باطلة؛ وهي على النحو التالي أ. شركة المفاوضة: وصئه عورتها عنده، أن يقول الثريكين تفاوضنا لنشترك في كل ما لنا وما علينا، ومال كل منهم

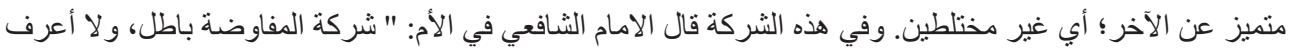

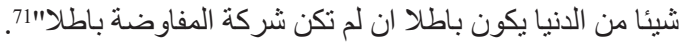

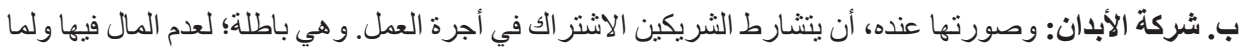

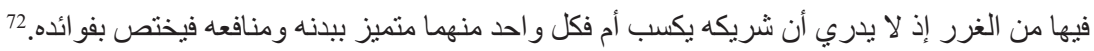

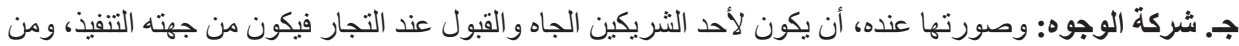
جهة غيره العمل، وهي أيضا باطلة.

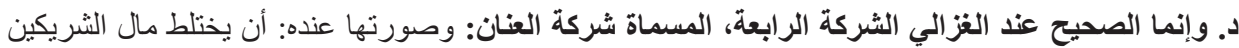

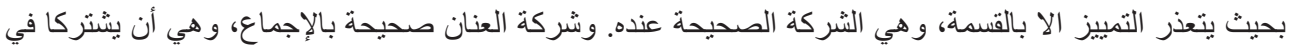

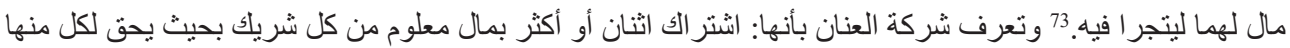

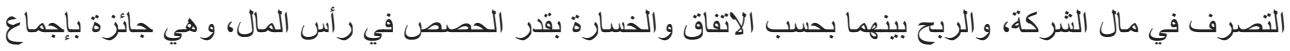

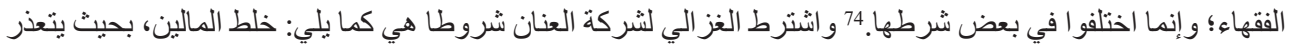

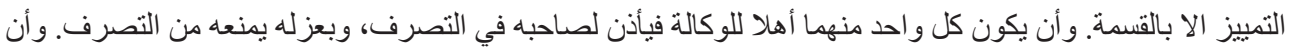

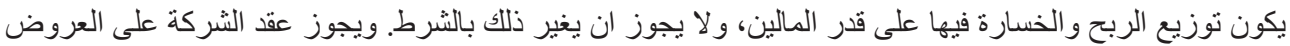

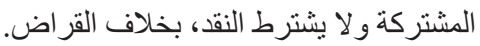

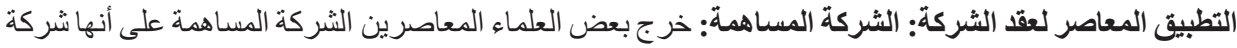

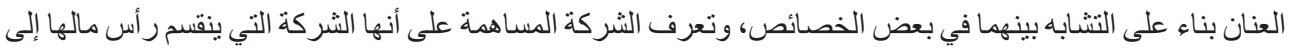

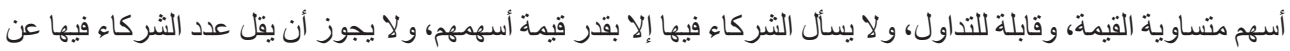

66 انظر : النجار، طلال أحمد، المضاربة المشتركة ومدى تطبيقها في المصارف الإسلامية في فلسطين-معوقاتها وتطويرها-، رسالة ماجستير،

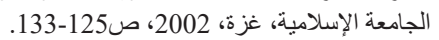
67 68 68 68 69 68 الثربيني، مغني المحتاج في معرفة معاني ألفاظ المنهاج، ج3، دار الكتب العلمية، بيروت، 2000م، ص221. 70 70 7 71 


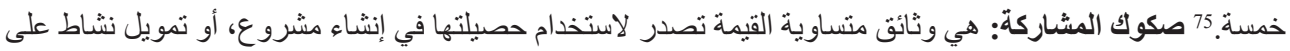

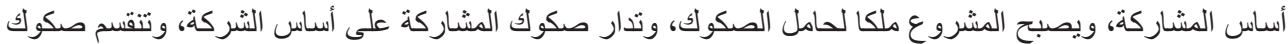

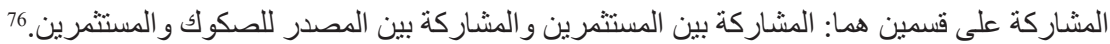

\section{المبحث الثاني: ضوابط الكسب المتعلقة بالمصلحة العامة عند الغزالي، وتطبيقاتها المعاصرة:}

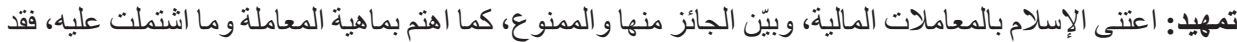

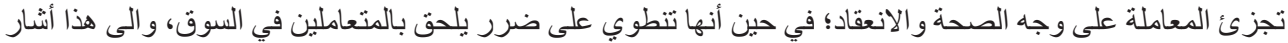

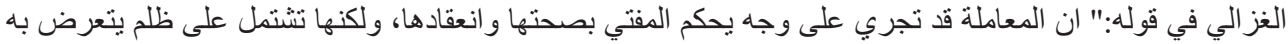

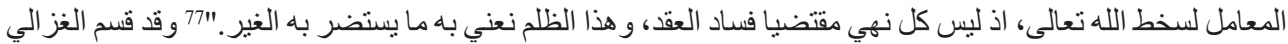

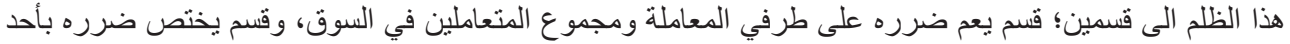
طرفي المعاملة. فيرى الغز الي أن الاحتكار ظلم عام، وذلك لما فيه من تضييق على الناس وما ينجم عنه من آثار اقتصادية

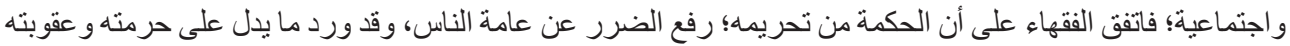
وكيفية التعامل مع المحتكرين وسلعهم. وكذلك مسألة تزييف النقود التي اعتبر ها الغز الي مما يتضرر به العامة؛ فهي أيضا من المسائل التي حظيت باهتمام

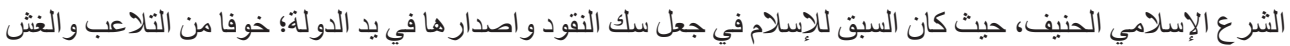
فيها؛ الا انه وبالر غم من ذللك تتعرض النقود بجميع أنثكالها للغش و التزوير منذ ظهور ها. وهذا المبحث يتناول مسألتي

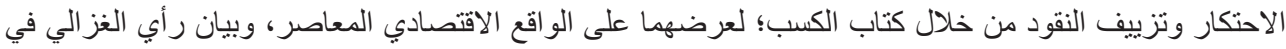
ضو ابط الكسب المتعلقة بالمصلحة العامة.

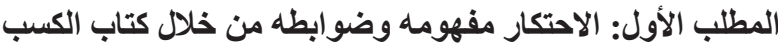

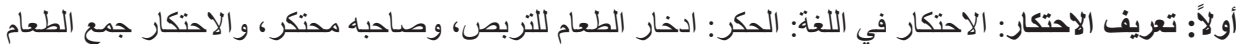

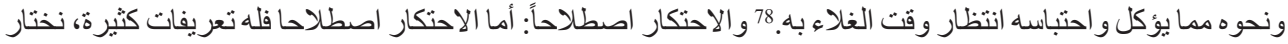

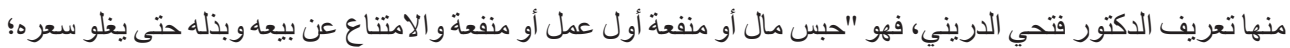
غلاء فاحش غير معتاد بسبب قلته أو انعدام وجوده في مظانه، ومع شدة حاجة الناس أو الحيوان أو الدولة اليه." 79 ويستخلص من هذا التعريف أن الاحتكار يشمل كل ما في احتباسه اضر ار بالناس، وهذا بإطلاقه يشمل كل شيء من المو اد الغذائية

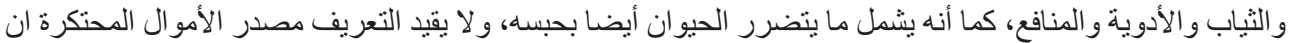

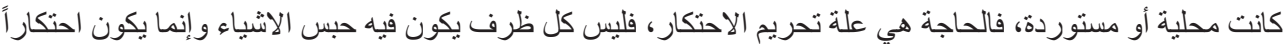

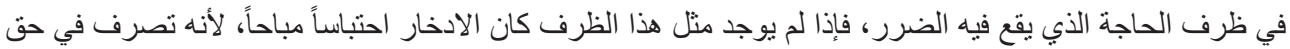

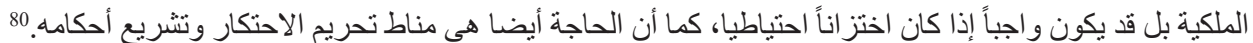

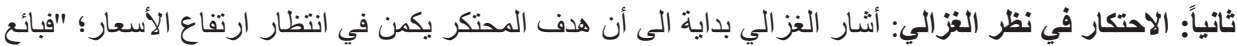

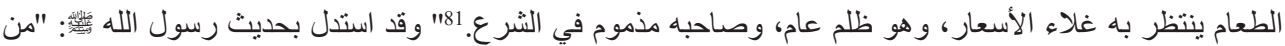
احتكر الطعام أربعين يو ما فقد برىئ من الله وبرئ الله منه. 82" فالاحتكار مما يتضر فور مجموع المتعاملين في السوق بسببه،

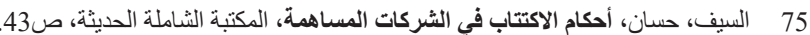

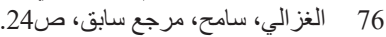

$$
\begin{aligned}
& 77
\end{aligned}
$$

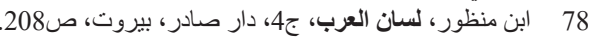

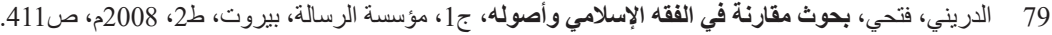

$$
\begin{aligned}
& 80 \\
& 81 \\
& 8281 \text { كتاب العلل، برقم 1174، كتاب الجرح و التعديل (3479)، كلاهما لابن أبي حاتم، و اسناده ضعيف. }
\end{aligned}
$$




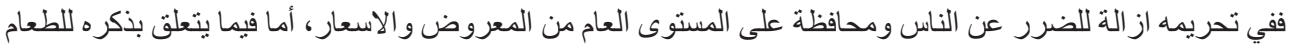

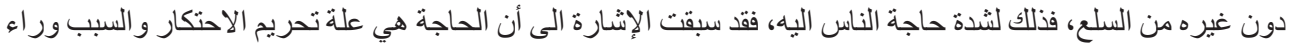

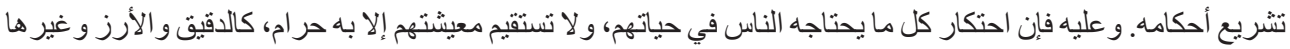

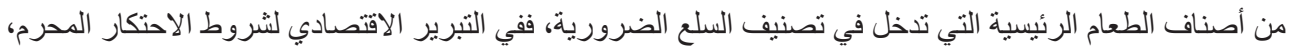

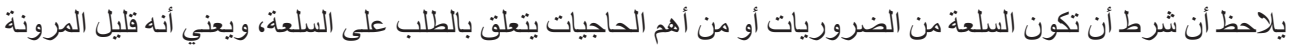

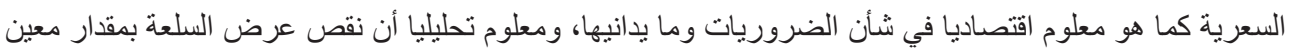

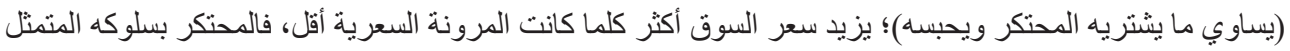

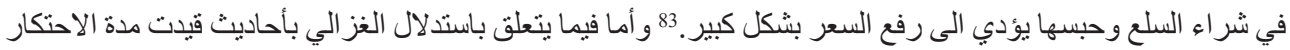

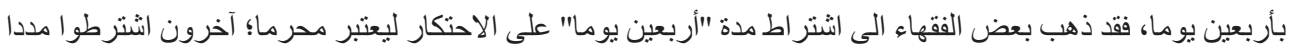
أقل. فاختلف الفقهاء على أربعة أقو ال:

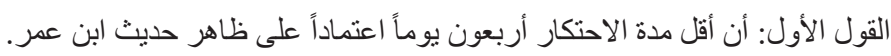

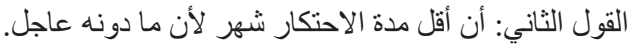

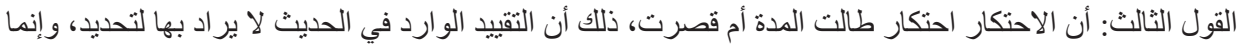

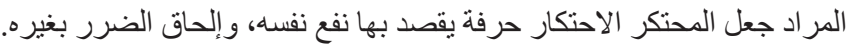

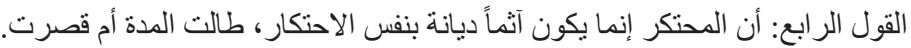

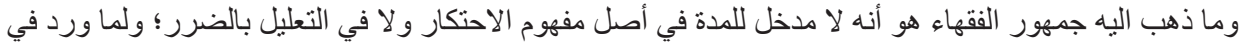

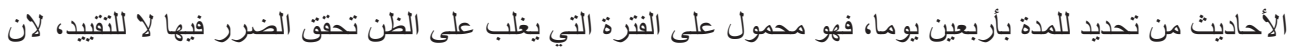

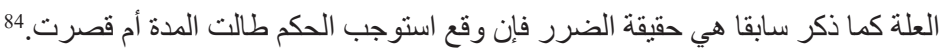

\section{ثالثثاً: النهي عن الاحتكار عند الغزالي مطلق؛ ويتعلق النظر به في مسألتين:}

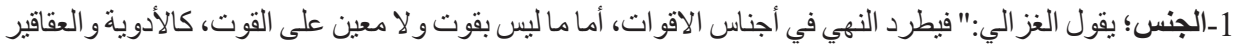

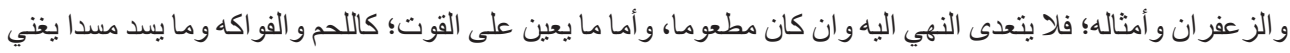

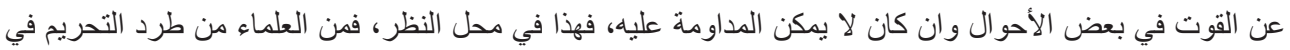

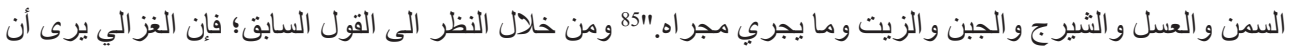

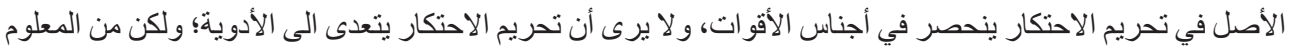

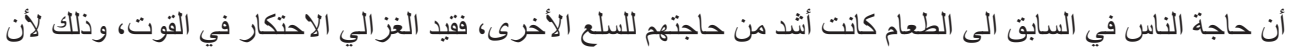
الضرر حتما يتحقق بحبسه.

أما الو اقع العملي اليوم فيفرض إطلاق الحكم على كل ما يحتاجه الناس من قوت و غيره، لأن العله من منع الاحتكار

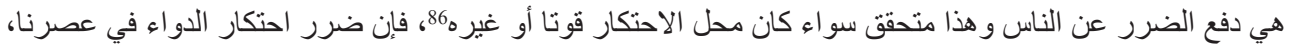

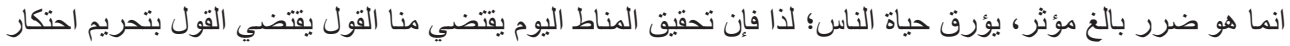

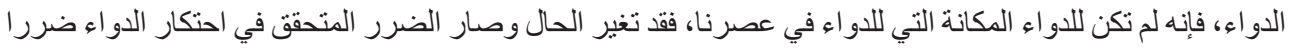

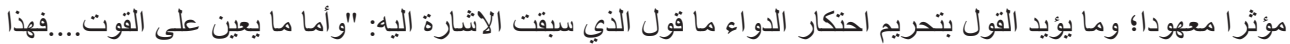
في محل النظر".87 مترو

83 انظر : مندور، عصام، الاحتكار وتطبيقاته المعاصرة بين الاقتصاد الإسلامي و الوضعي دراسة للأسباب والآثار و العلاج، مجلة الدر اسات التجارية

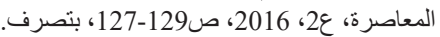
84 85 85 86 8 85

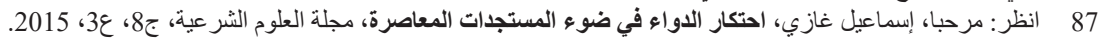


2-الوقت: يقول الغزالي:" فيحتمل أيضا طرد النهي في جميع الأوقات.... ويحتمل أن يخصص بوقت قلة الأطعمة

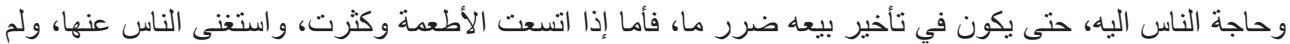
يرغبو ا فيها الا بقيمة قليلة، فانتظر صاحب الطعام ذلك ولم ينتظر قحطا، فليس في هذا اضر ار. و إذا كان الزمان زمان

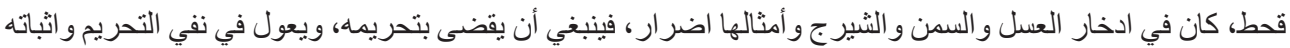

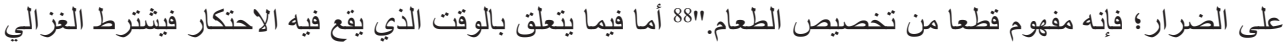

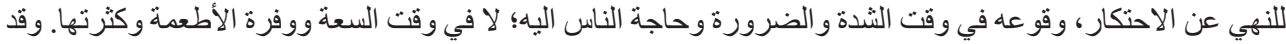

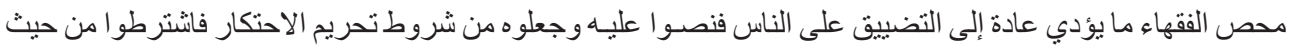

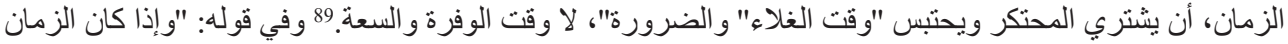

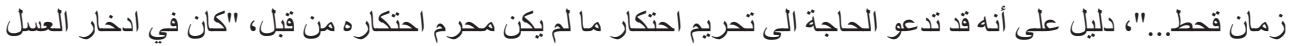

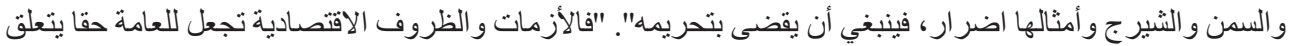
بما عند المالكين وحكم الاحتكار يعم التجار و غير هم في الظروف الاستثنائية كالجروب و الكو ارث و المجاعة والتهات الغلاء، فإذاذا

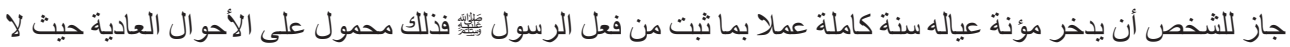

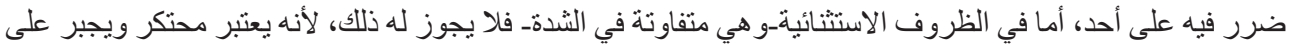

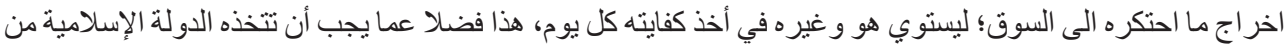

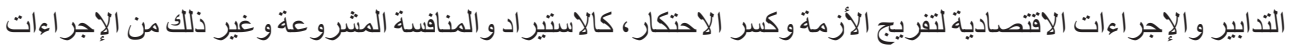

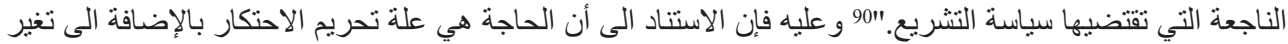
الأحوال والظروف الاقتصادية وظهور الأزمات والكوارث، وتغير الحاجات الإنسانية، أدى بدوره الى إلى إعادة النظر في لإني مفهوم الاحتكار وما ينطبق عليه.

رابعاً: التطبيق المعاصر لمفهوم الاحتكار عند الغزالي: تزامنا مع هذا البحث، يمر العالم بأزمة تفشي وباء كورونا

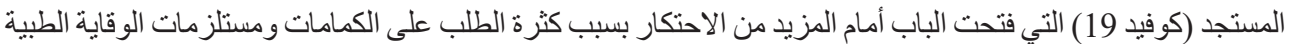

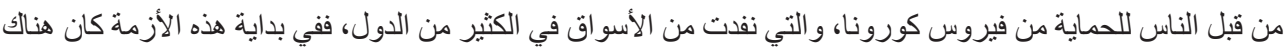

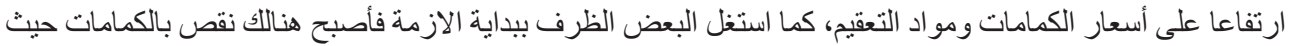

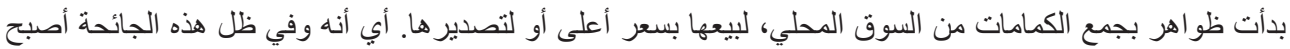

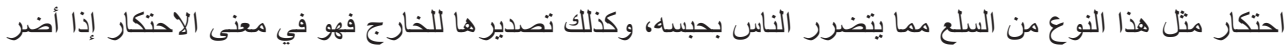

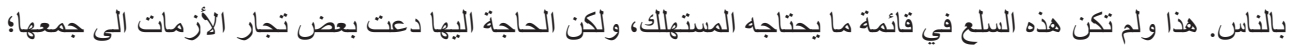

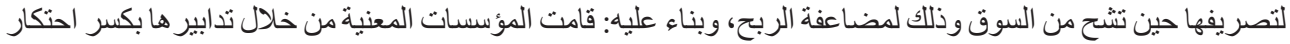

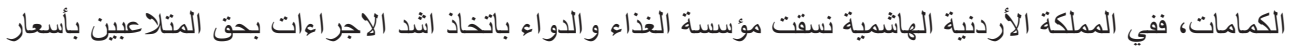

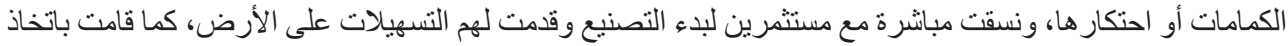

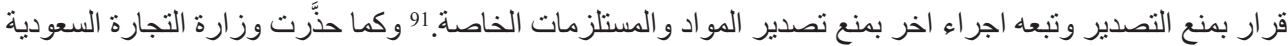

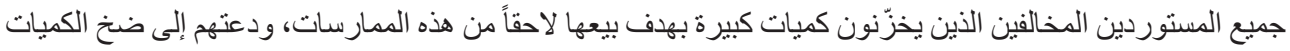

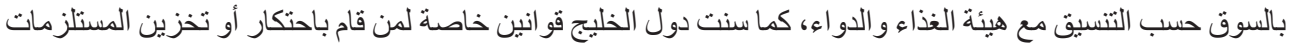

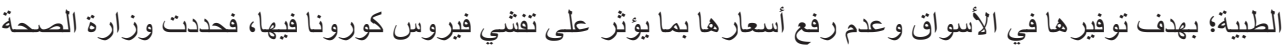

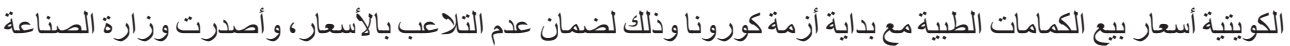


و التجارة و السياحة البحرينية قراراً يقضي بتحديد أسعار بيع الكمامات الطبية؛ لتفادي التلاعب في أسعار ها خلال الفترة

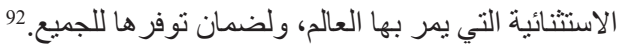

\section{المطلب الثاني: ضوابط التعامل بالنقد المزيف "العملة المزورة"}

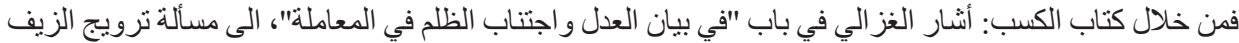

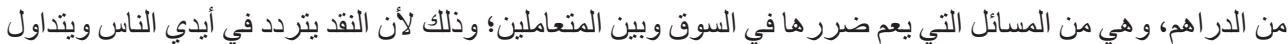

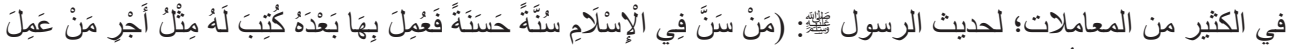

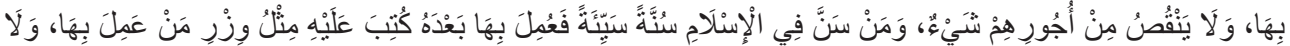

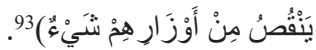
أولاً: الفرق بين تعريف النقد و العملة: النقود في اصطلاح الفقهاء: فتطلق على كل ما يكون مقبول قبو لا عاما كوسـيط،

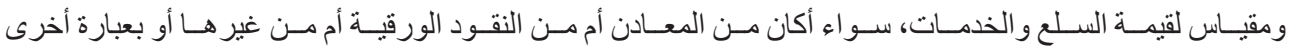

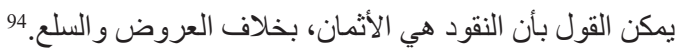

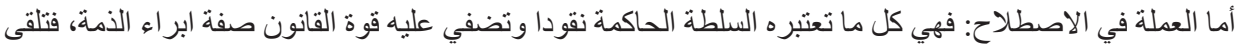

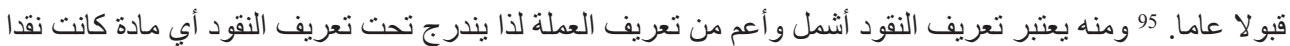

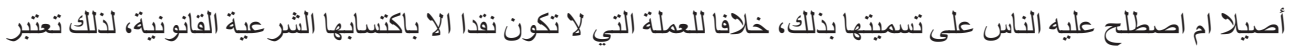
النقود عموم و العملة خصوص، فكل نقد عملة وليس كل عملة نقد.

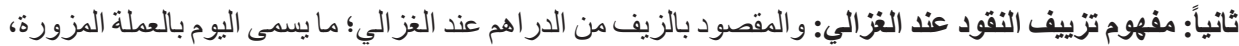

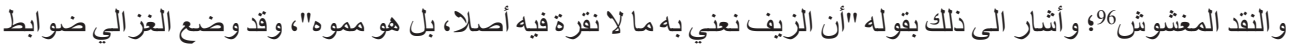
للتعامل مع مثل هذه النقود إذا وقعت في يد التاجر أو المتعامل، حتى لا تبق في حيز التداول في السوق ويعم ضرر ها على لثى

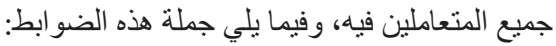

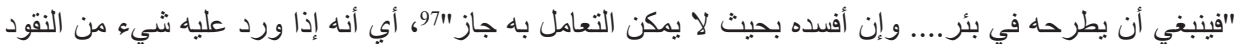

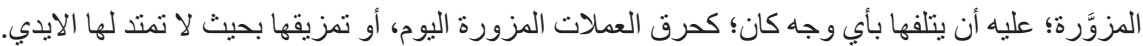

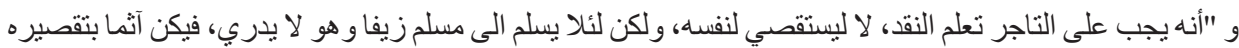

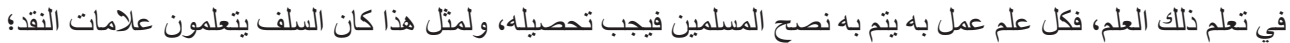

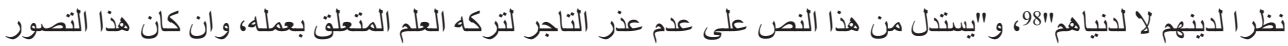

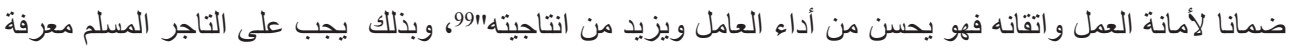

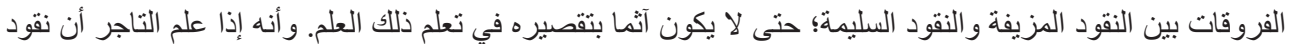

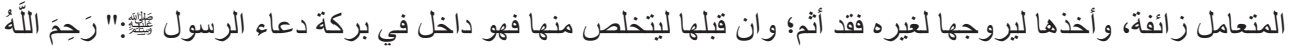

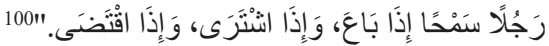

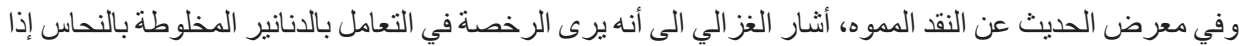
كانت نقد البلد، سواء علم مقدار أو نسبة الغش فيها أو لم يعلم "مقدار النقرة"، أما إذا لم يكن ذللك نقد البلد فلا يجوز التعامل 
به، و إذا كانت نسبة الغش في قطعة النقد التي يملكها المتعامل تختلف عما هو عليه نقد البلد، فيجب عليه أن يخبر بذلك.

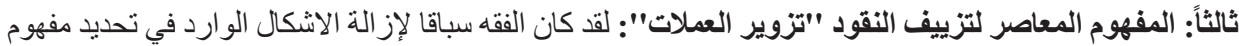

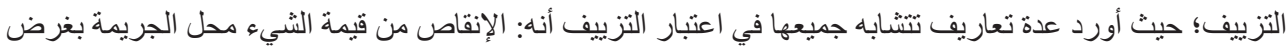

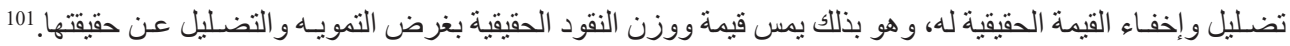

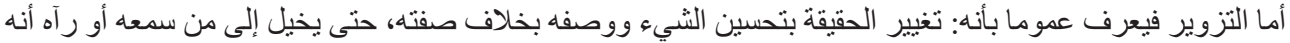

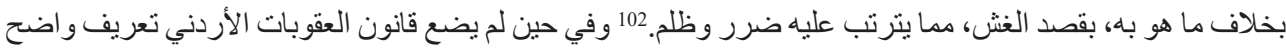

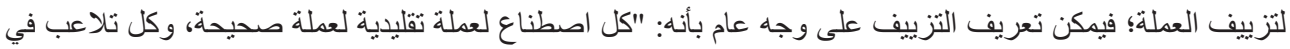

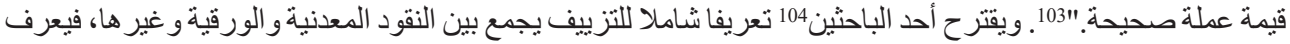
التزييف على أنه "تغيير يطر أ على صورة النقود، أو جو هر ها بقصد التمويه؛ ينقص من قيمتها"

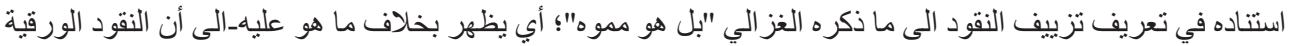

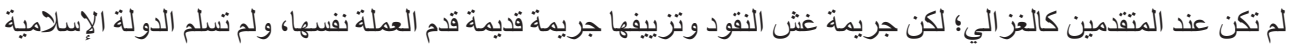

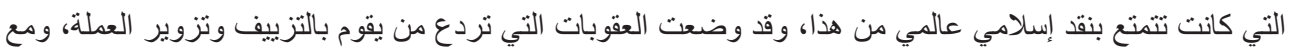

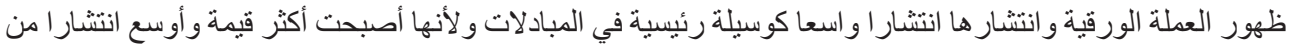

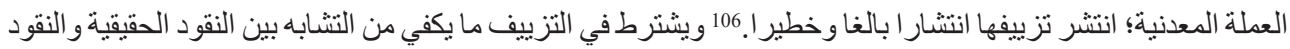

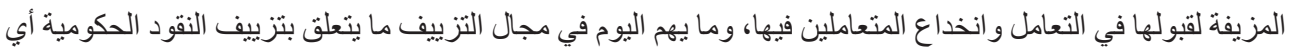

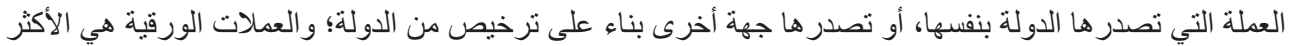

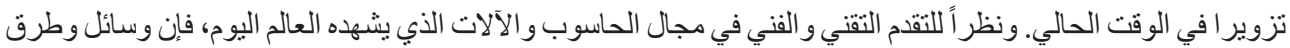

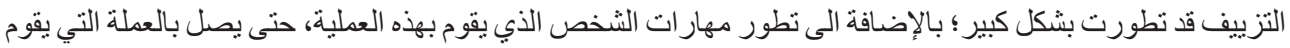

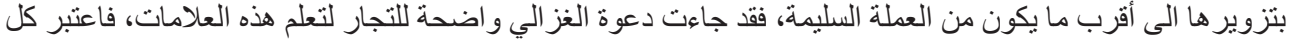

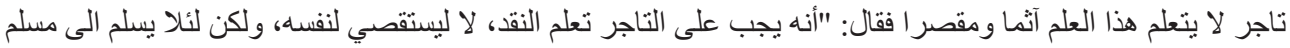

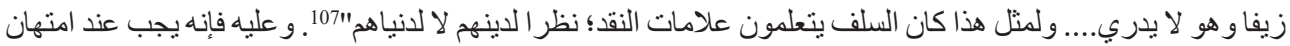

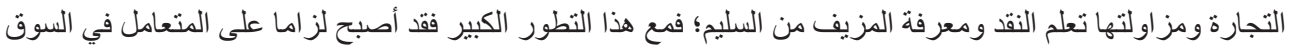

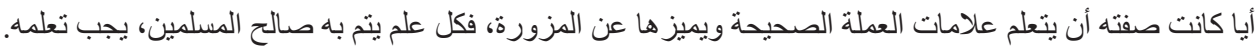

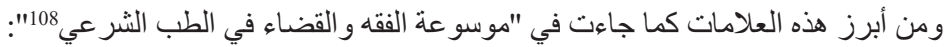

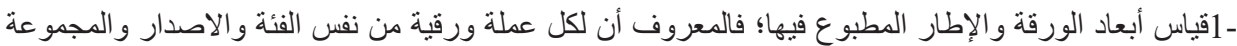

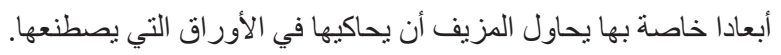
-2كما ان لملمس الورقة فضل كبير في التمييز بين العملات الصحيحة والمزيفة حيث تثميز الأور اق الصحيحة بملمس

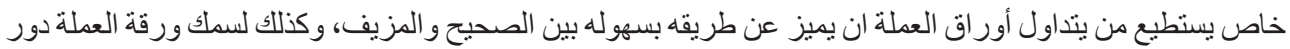

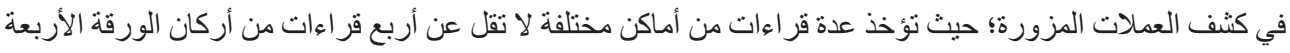

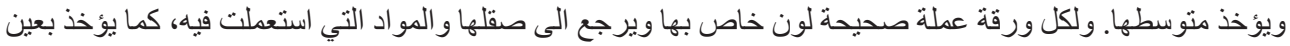

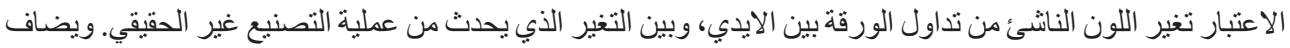

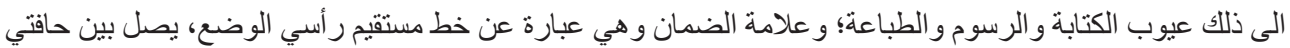

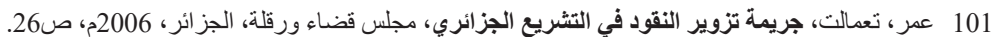

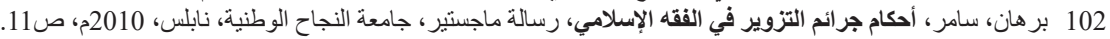

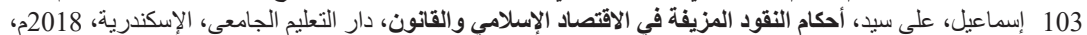

104 105 انظر: سميران، النقود المزيفة: أحكامها و آثار ها الاقتصادية في الفقه الإسلامي، الدليل الاكتكروني للقانون العربي، عمان، 2000م، ص6-74-7.

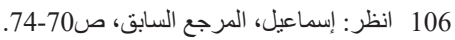
107 الغزالي، الإحياء، ص289. 108 الطباخ، شريف، وجلال أحمد، موسوعة الفقه والقضاء في الطب الثرعي، ج4، المركز القومي للإصدارات القانونية، القاهرة، 2006م. 
الورقة السفلى و العليا ومندمج في عجينتها، لا يرى لله لون على كل من سطحي الورقة، لكنه يرى جيدا عن تعريضها للضوء النافذ، أما النقود المزيفة فلا يرى لها علامة ضمان. 109 أما بالنسبة للعملة الأردنية؛ فتحتوي العملات الاردنية على فلى

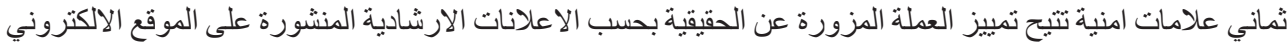
للبنأك المركزي الأردني:110 العلامة المائية: تحتوي على صورة مطابقة لصورة الملك الظاهرة على كل فئة من فئات النقا.

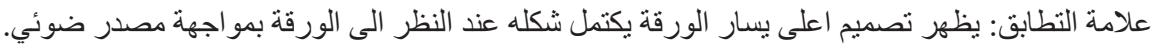
طباعة بارزة خشنة في اماكن متعددة.

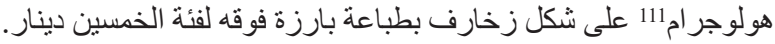

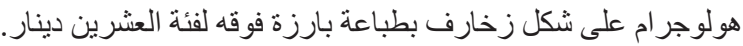
فويل فضي لامح على شكل زخارف اسلامية.

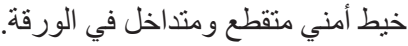
علامة بارزة لتمييز فئة ورقة النقا للمكفوفين.

\section{المبحث الثالث: معيار حماية المتعاملين في السوق عند الغزالي:}

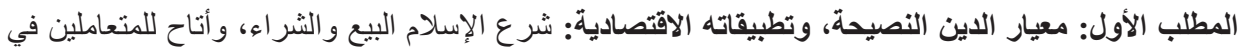

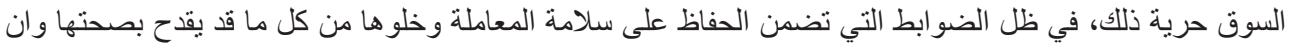

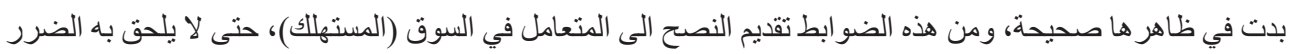

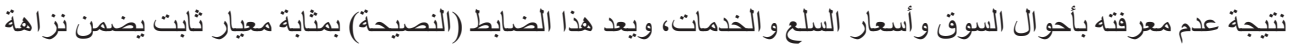

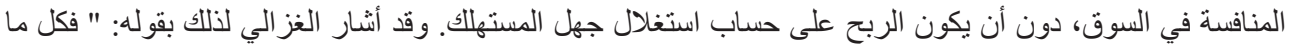

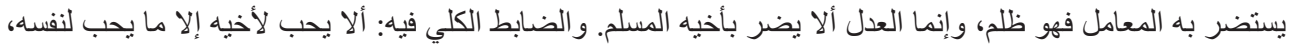

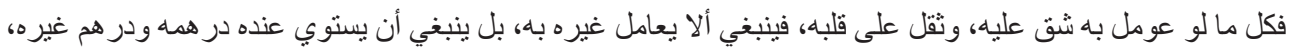

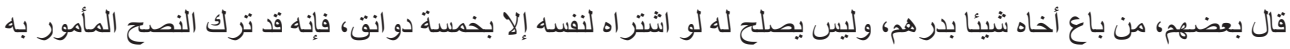

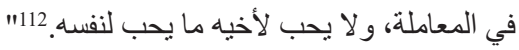

أولاً: التطبيق معيار الدين النصيحة في السوق عند الغزالي: من خلال النظر اللى ما أثنار اليه الغز الي يتبين أن معيار

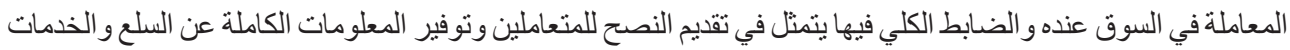

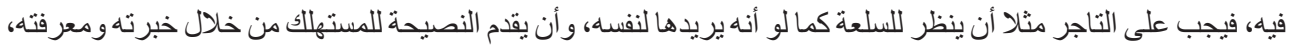

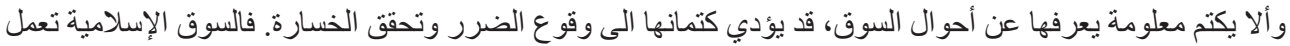

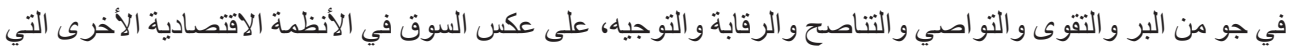

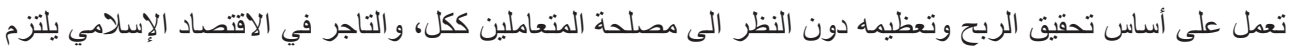

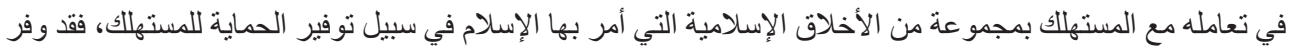

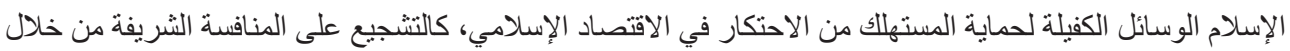

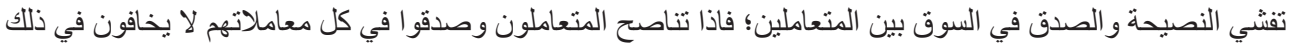

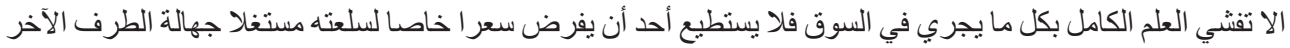


أو مدعيا بأن هذه السلعة لها مز ايا. 113 و عليه فإن توفر المعلومات الكاملة في السوق الاسلامية من خلال ما يقدمه المتعاملين

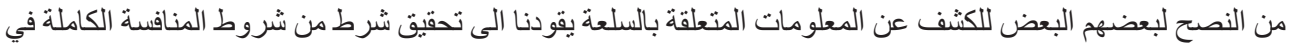

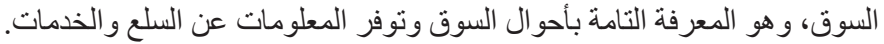

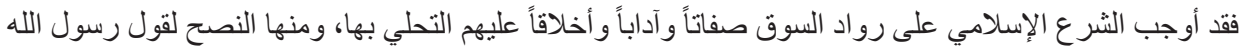

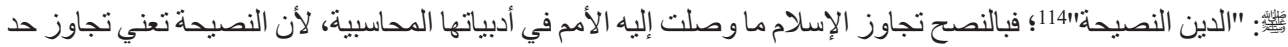

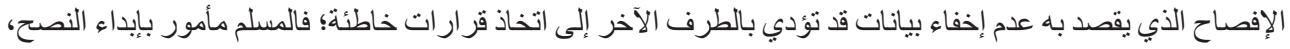

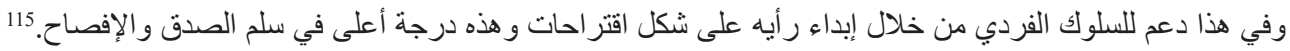

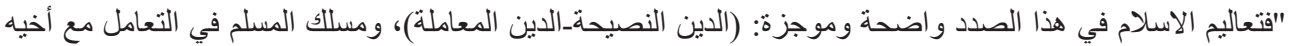
المسلم وفي اسداء النصح له، ركن من اركان اسلامه، ونستطيع أن نتصور مقتضيات هذا الركان الركن في مجال التنافس: فمثنا

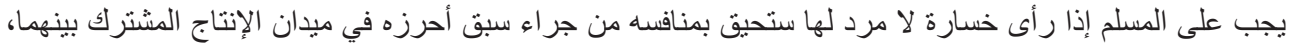

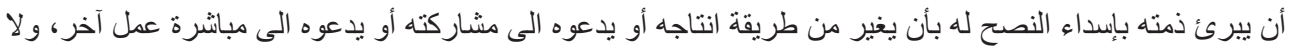

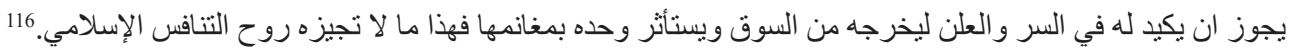

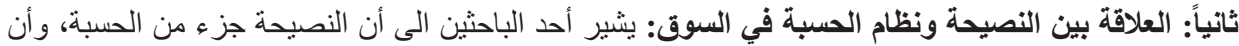

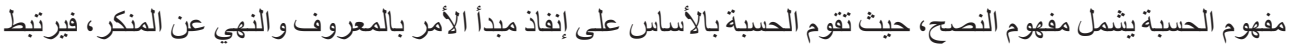

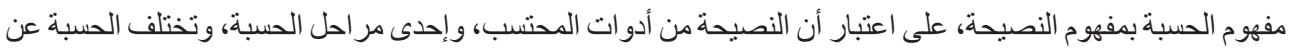

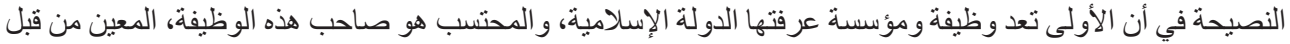

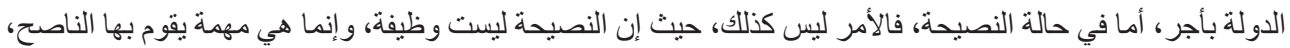
دون تكليف من جهة محددة117. فيتطلب الحديث عن المنافسة في السوق الاسلامية الحديث بالضرورة عن الهيثة الهيئة الإسلامية

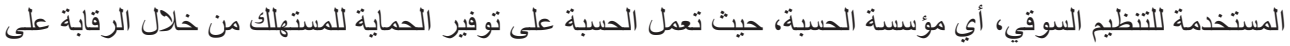

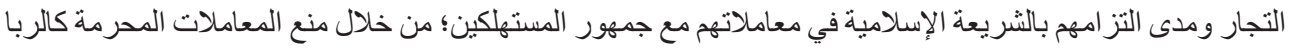

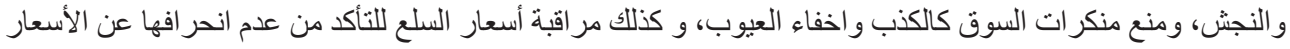

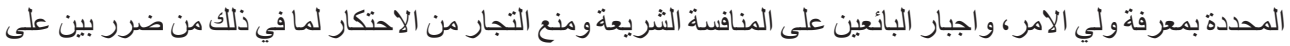

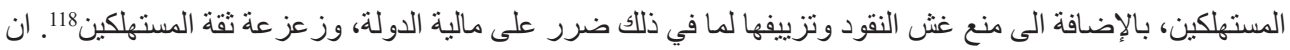

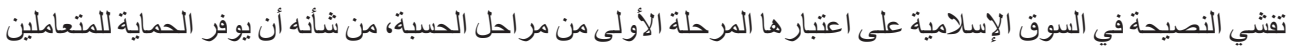

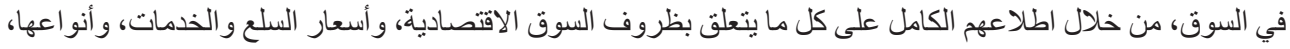

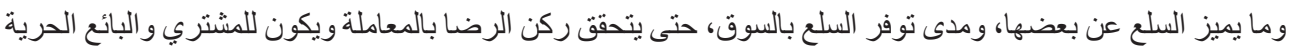

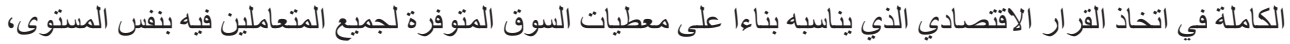

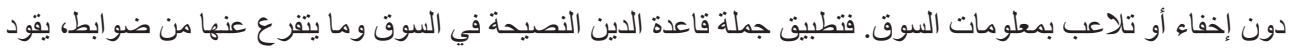

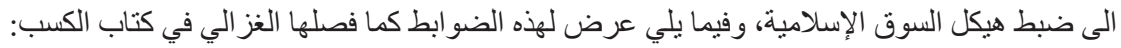

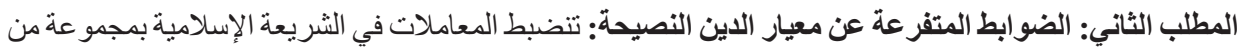

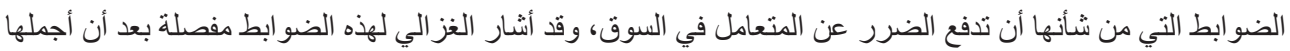

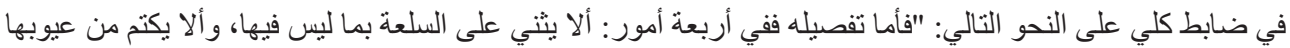

113 انظر: حسين، محمد علي، آليات حماية المستهلك في الاقتصاد الإسلامي، رسالة ماجستير، جامعة أم درمان الإسلامية، السودان، 2014م،

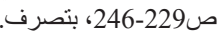

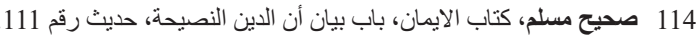

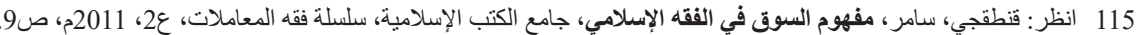

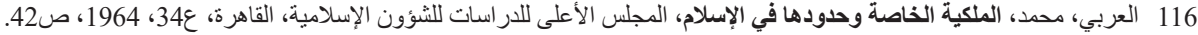

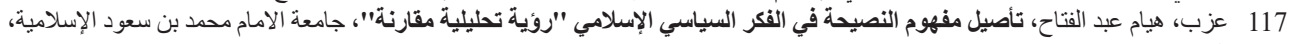


وخفايا صفاتها شيئا أصلا، و ألا يكتم في وزنها ومقدار ها شيئا، و ألا يكتم من سعر ها ما لو عرفه المعامل...لامتتع عنه."

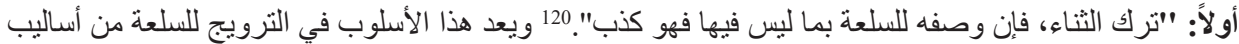

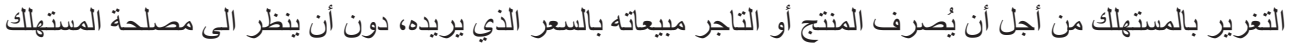

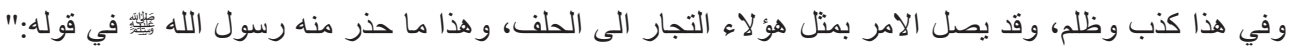

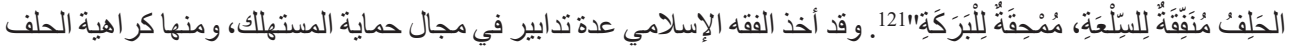

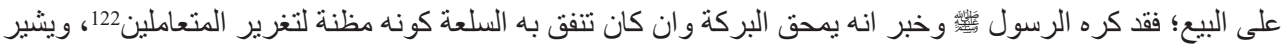

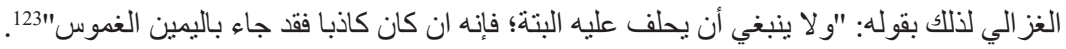

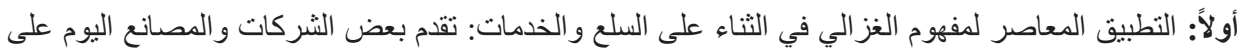

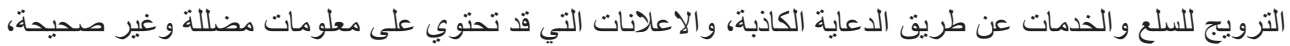

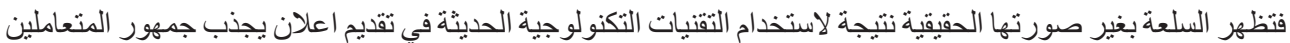

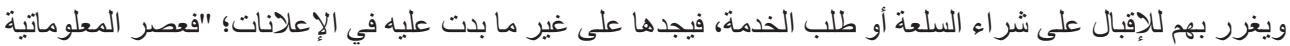

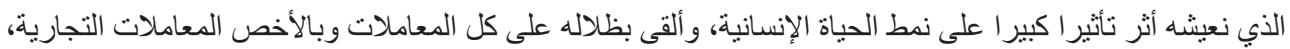

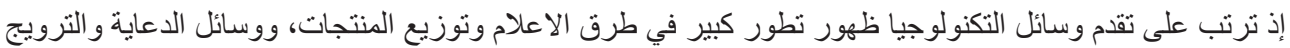

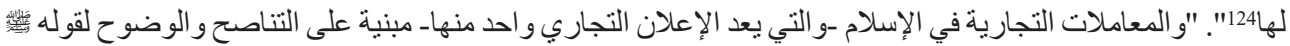

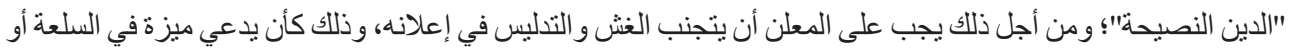

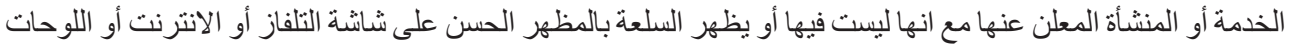

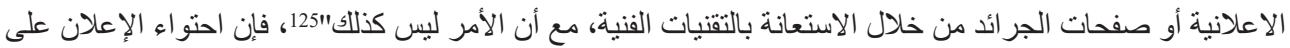

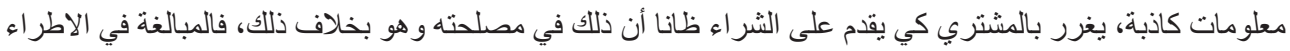

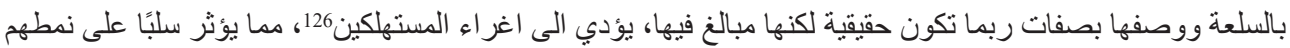

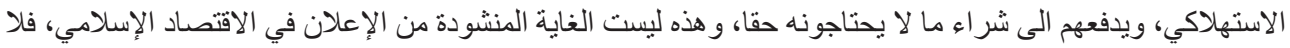

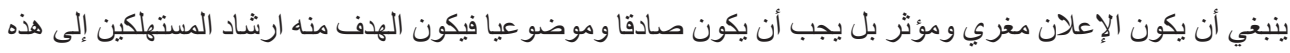

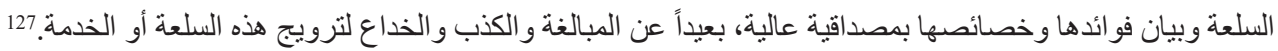

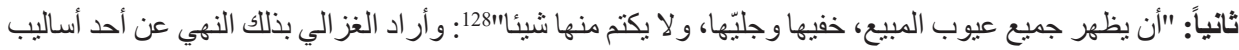

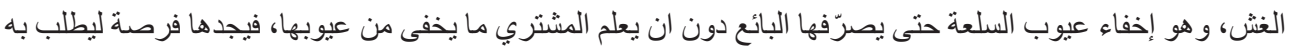

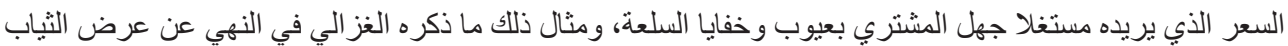

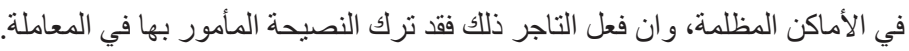

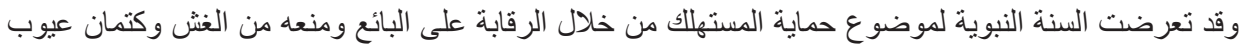

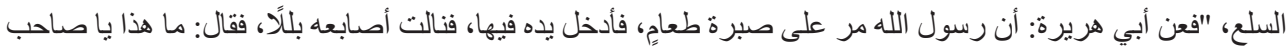

119 الغز الي، مرجع سابق، ص292.

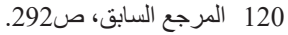

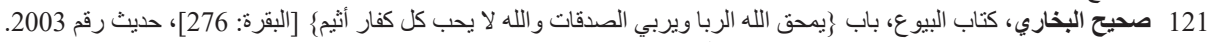

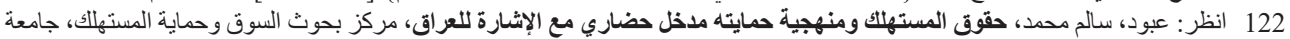

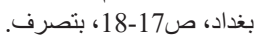

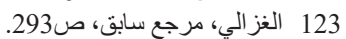

124 صالح، زاهر، حماية المستهلك في الفقه الإسلامي: دراسة مقارنة، أطروحة دكتور اة، جامعة القرآن الكريم و العلوم الإسلامية، السودان، 2017، ص95.

125 المناصبر، علي، الإعلانات التجارية مفهومها وأحكامها في الفقه الإسلامي، أطروحة دكتور اة، الجامعة الأردنية، عمان، 2007م، ص121.

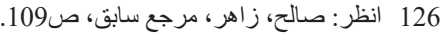

127 انظر : الصلاحين، عبد المجيد، الإعلانات التجارية احكامها وضوابطها في الفقه الإسلامي، مجلة الشريعة والقانون، الجامعة الأردنية، ع21،

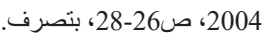

128 الغز الي، مرجع سابق، ص295. 
الطعام؟، قال: أصابته السماء يا رسول الله! قال: أفلا جعلته فوق الطعام كي ير اه الناس، من غش فليس مني. 129"؛؛ و عليه

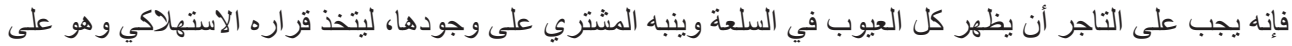

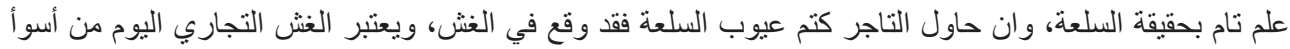

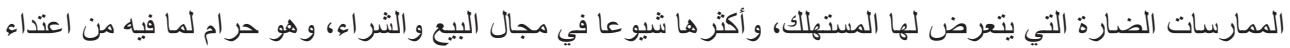
سافر على حقوق المستهلكين، فهو حرمان لهم من استهلاك سلعة أو خدمة بجودة ومو اصفات عالية، مما يؤثر سلبًا على صحة المستهالك ويهدد سلامته. 130 ثُالثاً: "الاّ يكتم في المقدار شيئا وذلك بتعديل الميز ان و الاحتياط فيه، وفي الكيل فينبغي أن يكيل كما يكتال"131. قال الله

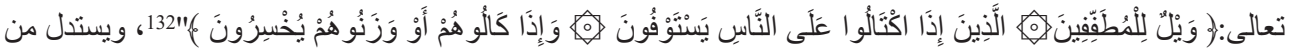

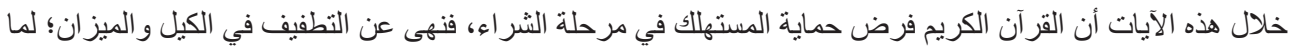

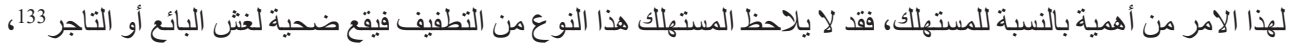

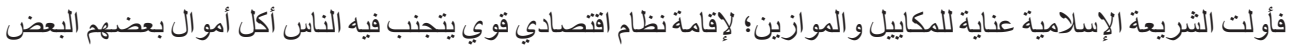
بالباطل، ويقل فيه ظهور الازمات و المشاكل الاقتصادية.

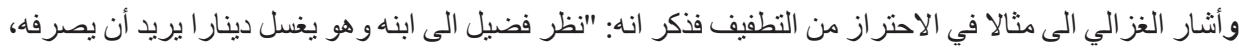

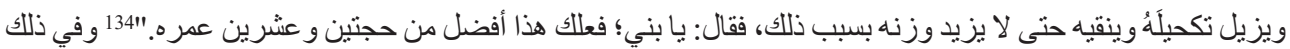

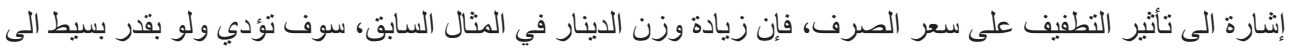

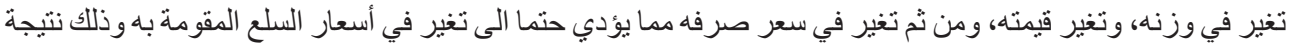

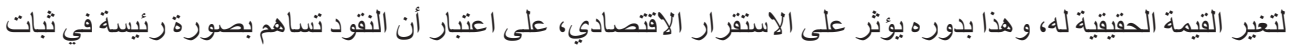

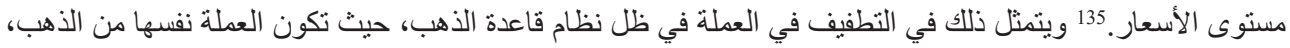

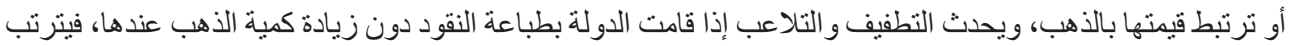

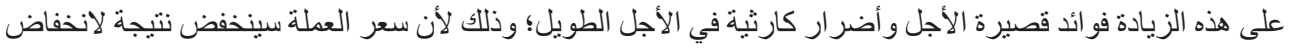

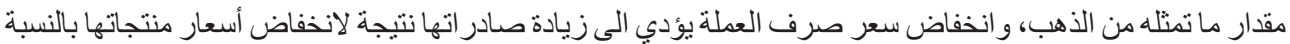

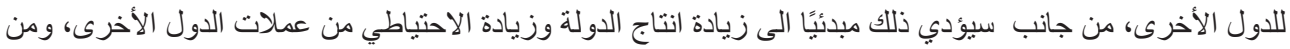

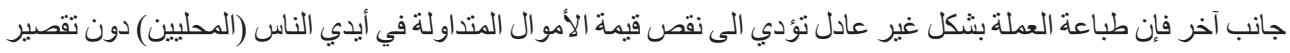

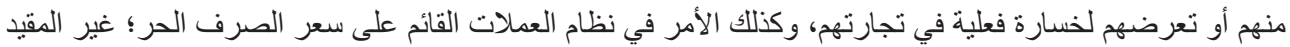

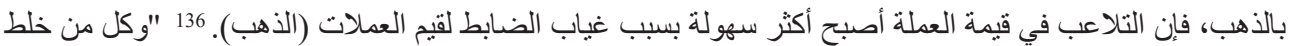

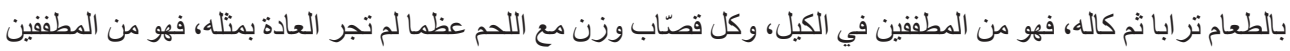

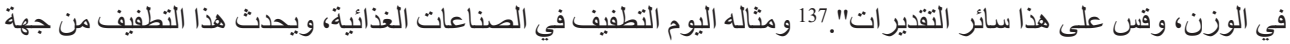

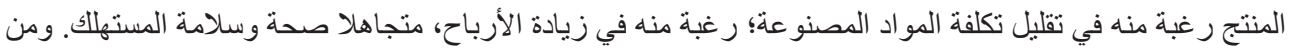

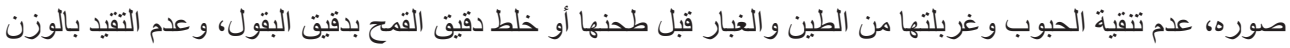

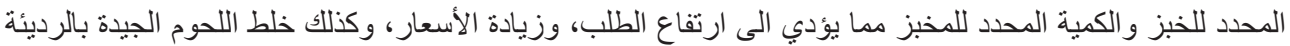

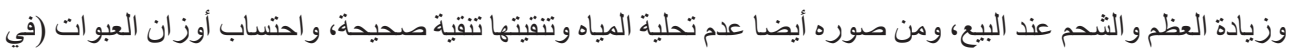

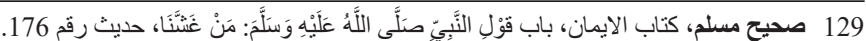

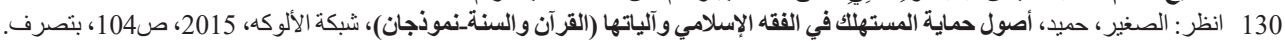

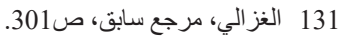

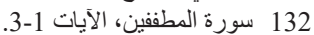

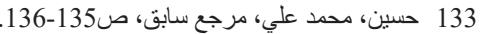

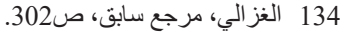

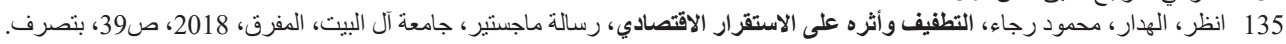

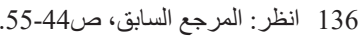
137 الغزالي، مرجع سابق، ص304. 


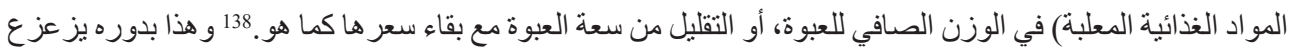

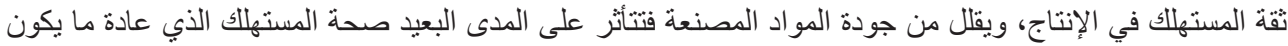

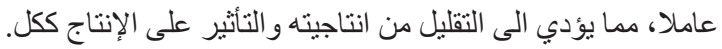

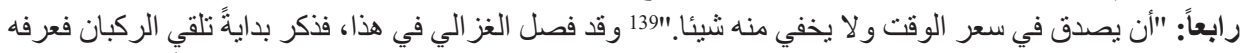

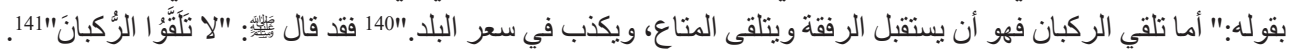

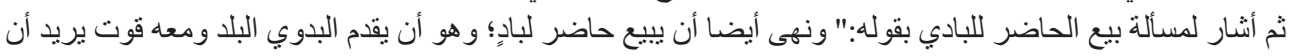

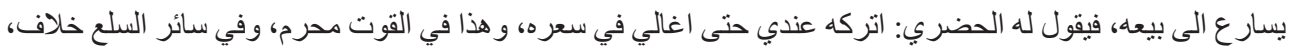

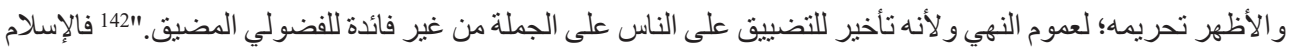

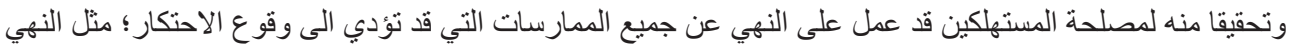

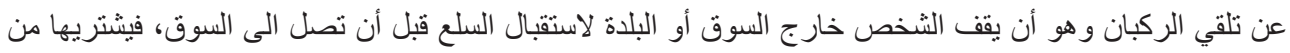

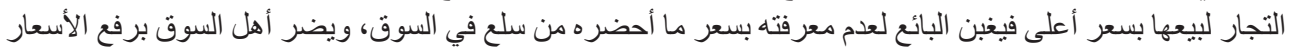

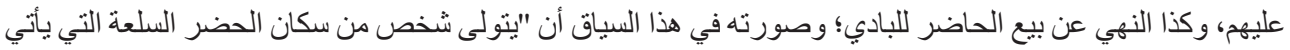

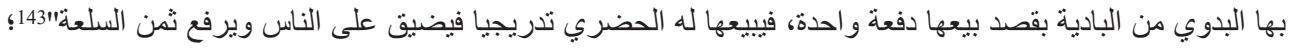

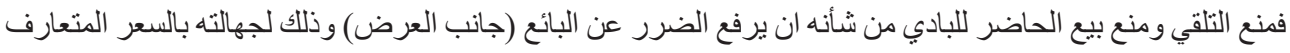

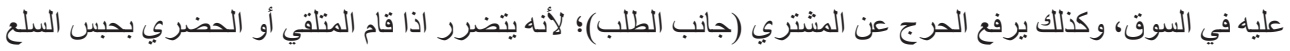

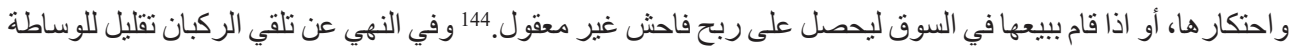

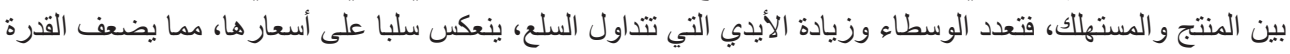

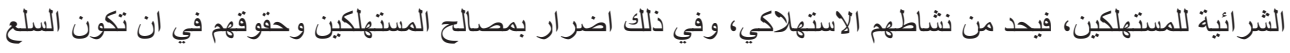

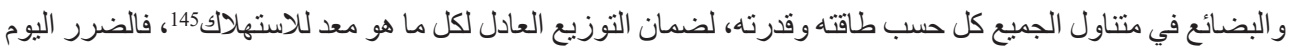
لا ينحصر فقط في حبس الطعام كما أشرنا سابقا.

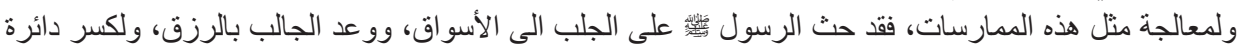

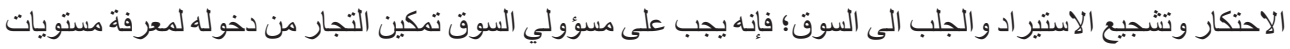

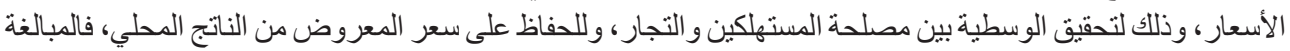

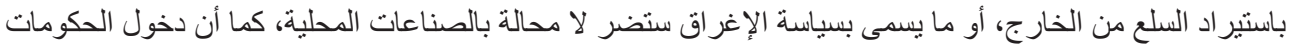

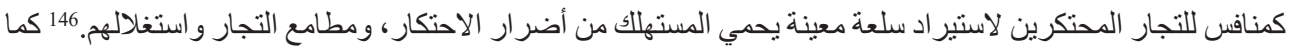

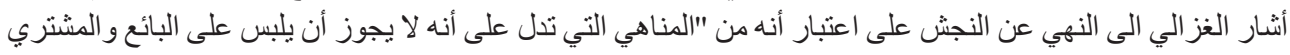

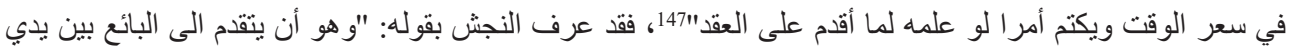

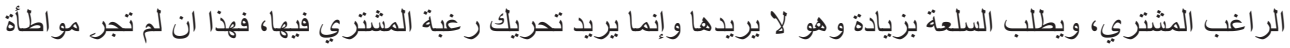

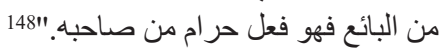

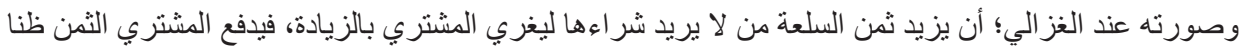

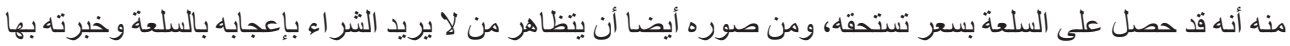

138 انظر : المصباحي، علي محمد، التطفيف: صوره و أحكامه، رسالة دكتور اه، جامعة أم درمان الإسلامية، السودان، 2009، ص195-194، بتصرف.

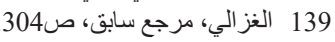

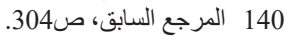

141 صحيح البخاري، كتاب البيوع، هل يبيع حاضر لباد بغير أجر ، و هل يعينه أو ينصحه، حديث رقم 2074.

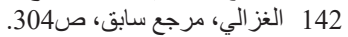

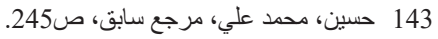

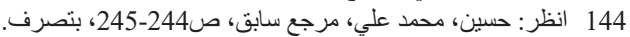

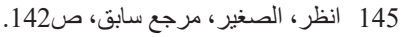

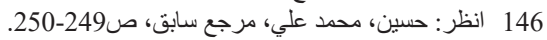

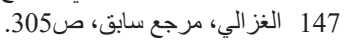

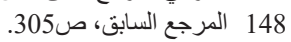


ويمدحها ليغر المشتري فيرفع ثمنها، أو أن يدعي صاحب السلعة ادعاء كاذبا أنه دفع فيها ثمنا معينا ليدلس على من يسوم. 149

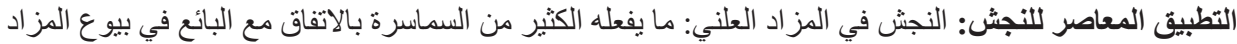

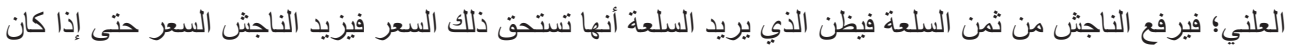
السعر مرتفعا توقف، وذهب المساومون فبلزم المشتري الثر اء بسعر لا تستحقه السلعة. 150

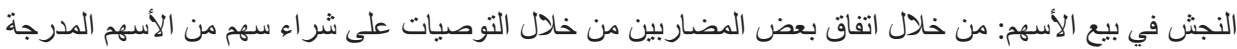

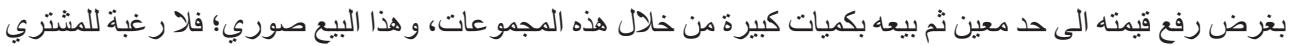

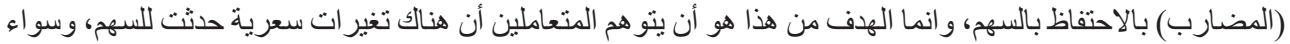

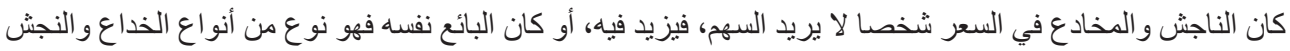
و التغرير المجمع على تحريمه، فهو يضر بأحد المتعاقدين على سبيل الخديعة. 151

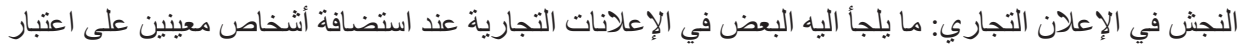

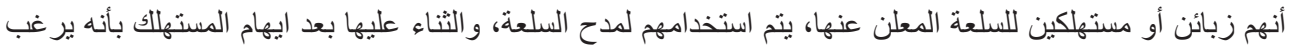

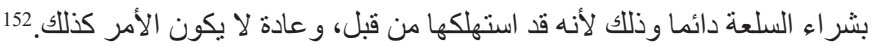

\section{الخاتمة}

الحمد لله في البدء و الختام، و الصلاة و السلام على رسوله، و على آله و أصحابه الكر ام. وبعد أن أتمدت در اسة وتحليل كتاب الكسب من كتاب احياء علوم الدين للإمام الغز الي -رحمه اللهـفهذه أهم النتائج و التوصيات:

1. يشكل كتاب الكسب للإمام الغز الي قاعدة غنية ومهمة من شأنها أن تضبط سلوك المتعاملين في السوق وأن

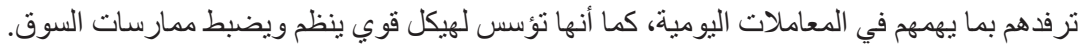

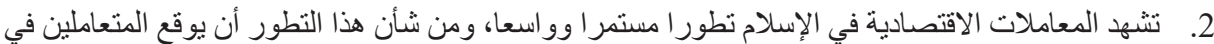

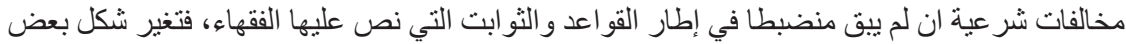

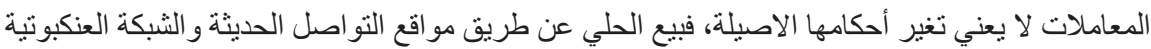
بدفع الثمن معجلاً و استلام الحلي من الذهب و الفضة، يعد صورة من صور الربا الذي يشترط فيه التقابض، و المخرج من هذا الوكالة، بأن يقبض الوكيل السلعة فور ال بعد دفع ثمنها.

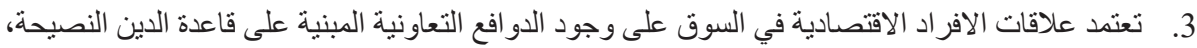

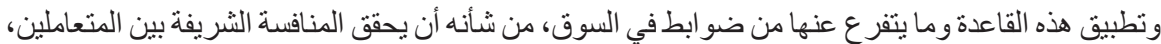

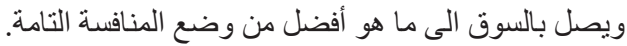

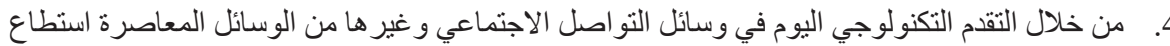
البعض أن يتلاعب بمو اصفات المنتج من خلال التسويف في التسويق و الاعلان.

ضرورة اجر اء البحوث و الدر اسات الاقتصادية المبنية على فكر فقهاء المسلمين عامة لبناء نظرية اقتصادية 
المفاهيم لتشمل كل ما يمكن أن يندرج تحتها، مثل الاحتكار و النجش، و غير ها. مر اقبة المعاملات الاقتصادية المستجدة وكذلك المعاملات التي تتم من خلال التعامل الالكتروني لضمان سلامتها

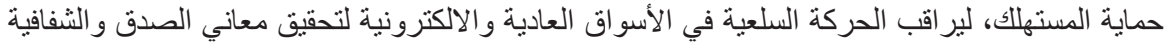

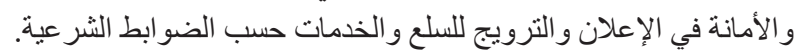

Peer-review: Externally peer-reviewed.

Conflict of Interest: The authors have no conflict of interest to declare.

Grant Support: The authors declared that this study has received no financial support.

\section{References}

قائمة المصادر والمراجع.

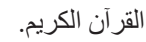
صحيح البخاري.

صحيح مسلم.

الغز الي، احياء علوم الدين، ج3، ربع العادات، دار المنهاج للنشر و التوزيع، جده، ط1، 2011م. (المرجع الرئيسي).

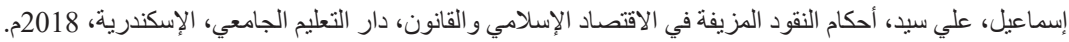

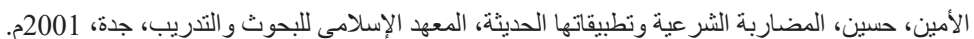
بن باز، هند عبد العزيز، بيع الذهب بالآجل وصوره المعاصرة، مركز التميز البحثي، جامعة الامام محمد بن سعود الإسلامية، الرياض.

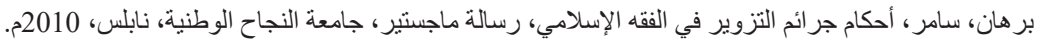
حسين، صدام عبد القادر، بيع الذهب و الفضة وتطبيقاته المعاصرة في الفقه الإسلامي، رسالة ماجستير ، الجامعة الأردنية، عمان، 2003م.

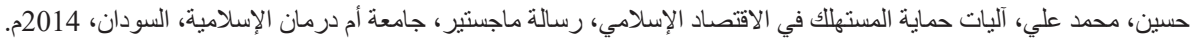

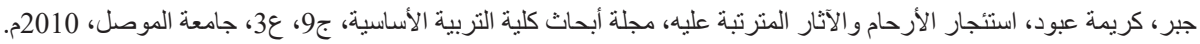

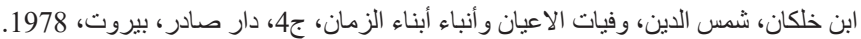

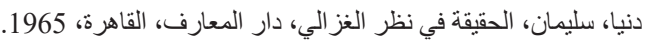
الداود، فهد بن عبد العزيز، خيار الغبن وتطبيقاته المعاصرة، مجلة البحوث الإسلامية، عالعان، 114، الرياض.

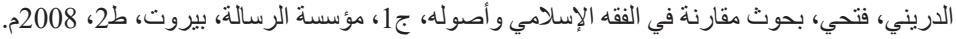

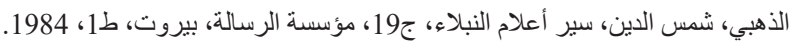
الزرقا، أنس، الأسواق المعاصرة غير التنافسية بين الفقه و التحليل الاقتصادي، مجلة جامعة الملك عبد العزيز: الاقتصاد الإسلامي، ج19،

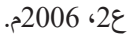

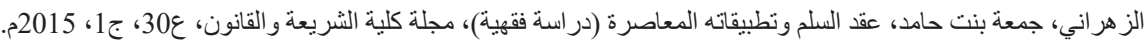

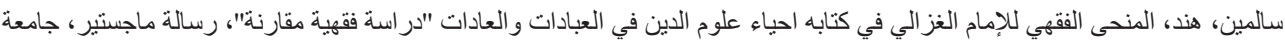

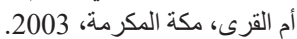

السبكي، تاج الدين، طبقات الثافعية الكبرى، ج6، دار احياء الكتب العربية، القاهرة، ص196.

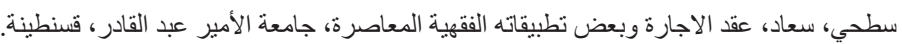

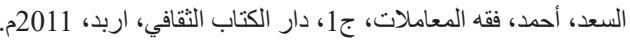

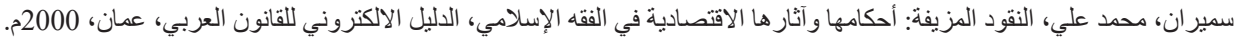
السيف، حسان، أحكام الاكتتاب في الثركات المساهمة، المكتبة الثشاملة الحديثة. الثافعي، الام، ج4، دار الوفاء للطباعة والنشر ، المنصورة، ط1، الناب، 2001. 
شبير، محمد، المدخل الى فقه المعاملات المالية، دار النفائس، عمان، ط2، 2010م. الثديفات، زيد قاسم، عقد السلم كأداة لتمويل المشرو عات الصغيرة و المتوسطة وتطبيقاته المعاصرة، رسالة ماجستير، جامعة آل البيت، المفرق، 2018

$$
\text { الثربيني، مغني المحتاج في معرفة معاني ألفاظ المنهاج، ج3، دار الكتب العلمية، بيروت، 2000م. }
$$

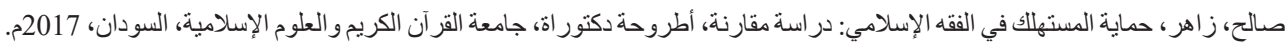
الصغير ، حميد، أصول حماية المستهلك في الفقه الإسلامي و آلياتها (القرآن و السنة_نموذجان)، شبكة الألوكه، 2015م.

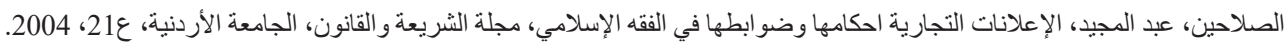
الطباخ، شريف، وجلال أحمد، موسوعة الفقه والقضاء في الطب الثرعي، ج4، المركز القومي للإصدار ات القانونية، القاهرة، 2006م. عبود، سالم محمد، حقوق المستهلك ومنهجية حمايته مدخل حضاري مع الإشارة للعر اق، مركز بحوث السوق وحماية المستهلك، جامعة بغداد.

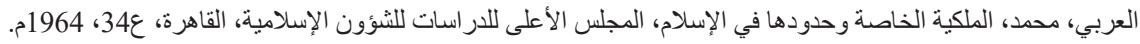
عزب، هيام عبد الفتاح، تأصيل مفهوم النصيحة في الفكر السياسي الإسلامي "رؤية تحليلية مقارنة"، جامعة الامام محمد بن سعود الإسلامية،

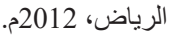

أبو العز، علي، عقود التمويل الإسلامي نتبيهات وملاحظات شر عية، دار النفائس، عمان، ط1، 2019م.

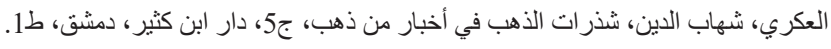

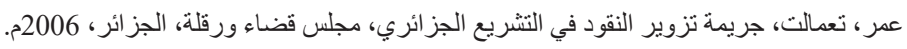

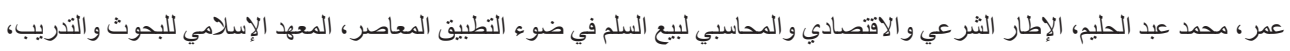
جدة، 2004م.

العمر اني، يحيى بن أبي الخير، البيان في المذهب الثافعي، ج5، دار المنهاج، جدة، ط1، 2000م.

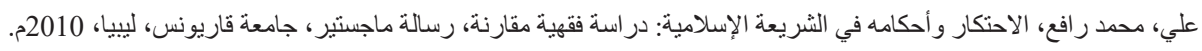

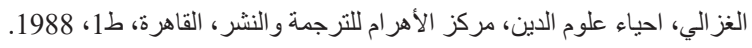

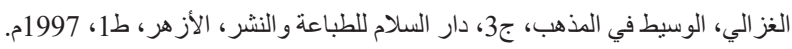
الغز الي، سامح، معوقات اصدار الصكوك الإسلامية كأداة لتمويل المشروعات الاقتصادية، رسالة ماجستير، الجامعة الإسلامية، غزة، الفيروز أبادي، القاموس المحيط، محمد بن يعقوب، مؤسسة الرسالة، بيروت.

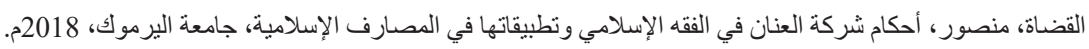
قنديل، محمد، حد الكفاية و أثره في تحقيق المصالح، مجلة كلية الثريعة والقانون، طنطا، ج35، ع2، 2020م.

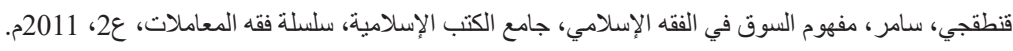
مرحبا، إسماعيل غازي، احتكار الدواء في ضوء المستجدات المعاصرة، مجلة العلوم الثرعية، ج8، ع3، 2015م. المصباحي، علي محمد، التطفيف: صور و وأحكامه، رسالة دكتور راه، جامعة أم درمان الإسلامية، السودان، 2009م. المناصير، علي، الإعلانات التجارية مفهو مها وأحكامها في الفقه الإسلامي، أطروحة دكتور اة، الجامعة الأردنية، عمان، 2007م. مندور، عصام، الاحتكار وتطبيقاته المعاصرة بين الاقتصاد الإسلامي و الوضعي در اسة للأسباب والآثار و العلاج، مجلة الدر اسات التجارية

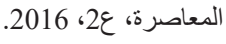

النجار، أحمد هشام، العملات الافتر اضية المشفرة: در اسة شر عية اقتصادية محاسبية، رسالة ماجستير، جامعة آل البيت، المفرق، 2019م. النجار ، طلال أحمد، المضاربة المشتركة ومدى تطبيقها في المصارف الإسلامية في فلسطين-معوقاتها وتطوير ها-، رسالة ماجستير، الجامعة

$$
\text { الإسلامية، غزة، 2002م. }
$$

الهدار، محمود رجاء، التطفيف و أثره على الاستقر ار الاقتصادي، رسالة ماجستير، جامعة آل البيت، المفرق، 2018م. 
